\title{
Em busca do conceito de valor
}

\author{
Maria José $\mathrm{G}$ uerra Figueiredo $\mathrm{G}$ arcia \\ Universidade Ibirapuera \\ Majogue@uol.com.br
}

Resumo: Este artigo analisa o modelo semiolingǘstico, enfocando especificamente 0 conceito de valor. 0 conceito semiolingǘstico de valor é aqui definido como um sintagma composto por três paradigmas: lingüístico, antropológico e tímicotensivo. Para desenvolver esta análise do conceito de valor, assumimos um percurso diacrônico pontuado por autores cujas obras marcam decisivamente a construção do modelo aqui utilizado. Assim, partimos de Saussure e Hjelmslev, chegamos a Greimas e incorporamos valiosas contribuições de Denis Bertrand, Jacques Fontanille e Claude Zilberberg. D escrevemos também algumas relações intertextuais e interdiscursivas no campo das Ciências Humanas e Sociais, tendo como base a discussão da questão do mercado, sob esse olhar construído a partir do modelo semiolingüístico.

Resumen: Este artículo hace un análisis del modelo semiolingüístico, enfocando la cuestión del valor. Por medio de un determinado concepto - el valor-, el objetivo es describir algunas relaciones intertextuales e interdiscursivas en el campo de las Ciencias Sociales. El concepto semiolingǘstico de valor es aqui definido como un sintagma compuesto de tres paradigmas: lingüístico, antropológico y tensivo. 
Foram muitas as indagações que contribuíram para a elaboração deste artigo, dentre elas: por que há alguns objetos que têm importância para o sujeito? Por que os objetos valem? Por que o sujeito - na concepção semiótica da palavra, aquele que opera a transformação em busca do objeto -, exatamente, sai à procura de um objeto? Por que alguns objetos merecem essa procura? Por que alguns objetos despertam desejo? É possível pensar essa questão do ponto de vista das Ciências Sociais? Q ual o significado dessa questão no quadro teórico das Ciências Sociais e, especificamente, no quadro da Semiótica Narrativa e D iscursiva?

Assim, este artigo analisa o modelo semiolíngüístico, enfocando a questão do valor. Este conceito semiolingǘstico de valor é aqui definido como um sintagma composto por três paradigmas: lingüístico, antropológico e tímico-tensivo.

O ponto de partida para estas análises é o modelo semiótico baseado em Saussure e desenvolvido a partir de Hjelmslev. É necessário ressaltar a proposta de Hjelmslev sobre 0 isomorfismo entre o plano da expressão e plano do conteúdo, afirmando as identidades formais entre os planos (Hjelmslev, 1975: cap. 9 a 11). As afirmações de Hjelmslev abriram o caminho necessário para o estudo do conteúdo que passou a ser alvo de trabalhos específicos e teve como uma das consequiências, nos anos sessenta, a publicação do livro Semântica E strutural de A. J. Greimas.

Partindo das propostas de Hjelmslev, Greimas traça uma análise do conteúdo baseada nas identidades formais com o plano da expressão - o conceito de sema ( unidades mínimas de significação), por exemplo, mostra correlação com o conceito fonológico de fema (componente da expressão). Tal aspecto é possível de ser percebido em seu livro Semântica E strutural, no qual se observa o passo dado em direção às preocupações com o conteúdo, direção essa que altera definitivamente a visão fundada em Bloomfield, na qual uma língua é "uma forma fonética que tem sentido, um sentido do qual nada se pode saber" (apud G reimas, 1976:13).

O modelo desenvolvido por Greimas, como situa Edward Lopes na obra Identidade e D iferença (1997:31), está inserido no campo da semiolingüística - uma das duas grandes tendências sobre a linguagem e 0 signo que se abrem a partir do final do século XIX.

Greimas, a partir dos trabalhos iniciados com a obra Semântica E strutural (1976), propõe um modelo de compreensão da construção social do sentido por meio de um percurso: 0 percurso gerativo do plano do conteúdo. 
Esse percurso indica uma disposição hierárquica de níveis de construção do sentido, disposta em patamares, os quais mostram estruturas imanentes capazes de gerar uma trajetória que vai do mais abstrato ao mais concreto. Trata-se de etapas sucessivas por intermédio das quais o sentido passa por uma organização, por uma ordem, o que permite concretizá-lo como significação. A significação é o sentido construído. Cada combinatória de formas produz um determinado sentido.

Temos, então, o nível elementar como a primeira modelização; isto é, investimentos semânticos mínimos são sobredeterminados por relações lógicas - contradição, contrariedade e complementariedade - e pela sensibilização tímica - uma categoria que revela um sistema de atrações e repulsões referente à forma como o ser se encontra situado num dado meio (G reimas, 1983:93).

O segundo nível está relacionado à presença do sujeito e suas relações com o objeto. Marca as articulações narrativas: a sucessão de estados de conjunção e de disjunção, os quais delimitam a trajetória do sujeito em busca do alvo do desejo.

O terceiro nível é o mais concreto deles, o nível discursivo, é o nível da enunciação - o fazer lingǘstico que tem como conseqüência a produção do enunciado.

Há, em cada um dos níveis, um componente sintático e um componente semântico. 0 componente sintático estabelece as regras do jogo de combinações e institui uma sintaxe relacional que opera na composição sintagmática. 0 componente semântico é responsável pelas determinações de sentido, as identidades e diferenças que irão compor os paradigmas de significação.

É este percurso que vamos discutir em função da construção do conceito de valor. Faremos uma leitura da proposta greimasiana clássica, incorporando contribuições da Gramática Tensiva (Fontanille e Zilberberg, 1996a e 1996b), bem como da obra de D enis Bertrand (1995).

Ao percurso de geração da significação, a Gramática Tensiva (Fontanille e Zilberberg, 1996a e 1996b) acrescentou contribuições, tendo algumas delas chegado a alterar a própria forma de concepção desse percurso. Dentre essas contribuições, uma delas nos parece extremamente adequada: trata-se da noção de campo, a qual poderia ser incorporada ao modelo greimasiano sem que com isso houvesse uma descaracterização do próprio percurso gerativo. 
Claude Zilberberg, já em sua obra Essai sur les Modalités Tensives de 1981, propõe compreender o sema como uma "massa sêmica" (Zilberberg, 1981:7) variando entre dois estados tensivos - tensão e relaxamento. Instala-se aí a continuidade sobre a descontinuidade assumida desde Semântica E strutural: "A única forma de focalizar, atualmente, o problema da significação consiste em afirmar a existência de descontinuidades..." (1976:27). A noção de campo vem privilegiar a continuidade, situar os níveis de construção da significação como campos de atuação possibilita caracterizá-los como pólos que exercem forças, potencializando as articulações que ali se desenvolvem.

Teríamos, assim, o campo elementar da significação com a carga semântica mínima sobredeterminada por uma massa tímico-sensível; e o campo discursivo, responsável, por meio de estratégias que se estabelecem entre enunciador e enunciatário, pelas projeções do sentido na figurividade de superfície. Trata-se de campos potencializados exercendo forças, as quais determinam uma massa contínua na significação. Entre esses dois campos situa-se a narrativa, 0 eixo narrativo, marcando a descontinuidade, a ruptura, as transformações.

Essas propostas já estão também esboçadas na obra de Greimas e Fontanille (1993), Semiótica das Paixões, quando os autores abordam as questões referentes à continuidade e à descontinuidade na construção do sentido. O bserva-se então a trajetória percorrida por G reimas afirmando as descontinuidades em Semântica E strutural e reavaliando essas propostas mais tarde com Jacques Fontanille. Essas análises sobre questões referentes à continuidade e descontinuidade acabam por direcionar, com um pouco mais de clareza, a questão da conversão de níveis, tão discutida pela Semiótica dos anos setenta. Tudo isso nos habilita a trabalhar com 0 percurso gerativo, incorporando essas alterações ao modelo clássico proposto nos anos setenta.

No percurso iniciado por Saussure, a questão do valor sempre preocupou vários autores. Um desses autores é D enis Bertrand (1995), que aponta uma forma de compreender o caminho percorrido pela Semiótica para chegar à construção do conceito de valor.

Bertrand mostra que a Semiótica, durante algum tempo, não se preocupou exaustivamente com a enunciação. Houve mesmo uma certa resistência em integrar o problema da enunciação. Isto pode ser constatado nos livros Semântica E strutural (1976) e D u Sens II (1983), nos quais há a predominância da análise da narrativa e da análise da semântica fundamental. 
A teoria semiótica propõe uma neutralidade de seu ponto de vista, abstraindo sua própria enunciação. Há, assim, uma certa "ética semiótica" em função de um enfoque científico. No entanto, a Semiótica se impõe como uma axiologia e seus trabalhos versam sobre 0 valor. 0 valor para a Semiótica acaba por assumir um sentido mais amplo, uma concepção não apenas limitada ao "objeto de valor". O discurso é um jogo de valores para seu sujeito. 0 esquema narrativo canônico é uma organização sintagmática da busca do objeto do desejo. 0 sentido é dimensionado a partir da construção do valor.

Nesse contexto, Bertrand propõe uma forma de análise do percurso semiótico traçado pela construção do conceito de valor a partir da articulação de três noções diferentes: a lingǘstica, a antropológica e a filosófica.

A concepção lingüística está ligada à determinação semântica elementar. Os traços sêmicos, que compõem o lexema, serão atualizados no momento da enunciação: os traços sêmicos carregam identidades e diferenças discurso. 0 lexema estabelece um objeto lingǘstico virtual que, a partir da manifestação discursiva, fixa e determina o valor nas diversas configurações temáticas e figurativas.

A concepção antropológica pode ser entendida como interação entre sujeitos, abrangendo as relações sócio-culturais como um todo. É a narratividade como circulação e comunicação de valores. Os contratos estabelecidos e a ruptura desses contratos marcam a transferência de valor.

Finalmente, a concepção filosófica apresenta a sensibilização, a continuidade sobredeterminando as descontinuidades narrativas. As duas concepções anteriores estão ligadas aos estudos semióticos dos anos sessenta e setenta: 0 desenvolvimento das pesquisas ligadas ao quadrado semiótico e à noção de valor lingüístico; e, posteriormente, o estudo da narratividade com base na Antropologia. A partir do final dos anos oitenta, a preocupação com a figuratividade, paixões, ética e estética marca uma outra concepção.

Neste movimento, a Semiótica, mesmo sem deixar de lado seus fundamentos fixados a partir da semântica elementar e da narratividade, caminha em direção à semiótica sensível, na qual não há mais oposições radicais. As relações são, agora, estabelecidas não apenas como interferências entre níveis descontínuos, mas como campos que conferem uma continuidade sobredeterminando as descontinuidades. 
Seguimos, inicialmente, a diretriz proposta por Bertrand: compreender o conceito de valor como um sintagma composto por três paradigmas, aos quais esse autor chamou de lingüístico, antropológico e filosófico. Entretanto, acrescentamos algumas alterações na forma de compreensão desses paradigmas.

Em primeiro lugar, para analisar o paradigma lingüístico, fomos buscar os fundamentos da determinação semântica no valor signo, chegando a Saussure com os conceitos de identidade e diferença, oposições lógico-conceptuais, o que confirma nosso compromisso com o enfoque semiolingǘstico do valor.

Quanto ao segundo paradigma, o valor antropológico, fomos a Greimas em seu artigo “Un problème de sémiotique narrative: les objets de valeur"(Greimas, 1983:19-48), a partir do qual analisamos as articulações narrativas baseadas nas relações fixadas no enunciado elementar entre sujeito e objeto e os desdobramentos possíveis dessas relações.

Em terceiro lugar, para o que Bertrand chamou de componente filosófico, optamos por privilegiar as conseqüências das sobredeterminações sensíveis nas relações entre sujeito e objeto, produzindo uma alteração na forma de subjetividade e de objetividade projetada nos discursos. Assim, ao invés de "filosófico" optamos por chamar de paradigma tímico-sensível, privilegiando as sensibilizações tímicas

Examinaremos, a seguir, os paradigmas que compõem o conceito de valor. As divisões efetuadas são balizas no direcionamento do texto. Entretanto, não estabelecemos tópicos de abordagem exaustiva de cada um dos paradigmas isoladamente, porque há uma profunda interrelação entre esses componentes. A combinação sintagmática desses paradigmas impõe uma sintaxe relacional, na qual há interação entre campos de interferência mútua, o que impede uma segmentação mais rigorosa.

\section{Paradigma lingüístico - o campo das equivalências}

Para analisar o paradigma lingüístico, tomaremos as afirmações de Fontanille e Zilberberg (1996), as quais nos indicam a necessidade de voltarmos a Ferdinand de Saussure. As propostas desses autores, tanto sobre valor, quanto sobre valência, são elaboradas com base em definições sintagmáticas e paradigmáticas. Isto mostra que o trabalho, mesmo discutindo e redimensionando o conceito de valor, é, também, uma pesquisa pautada no Curso de L ingǘstica $\mathrm{G}$ eral. Trata-se, portanto, de um trabalho semiolingǘstico, pois analisar sintagma e paradigma é 
considerar 0 eixo das simultaneidades e o das sucessões nos moldes propostos pelo mestre de Genebra.

Importantes considerações sobre o conceito de valor estão traçadas no C urso de L ingüística $\mathrm{G}$ eral. Saussure mostra que "a língua constitui um sistema de valores puro que nada determina fora do estado momentâneo de seus termos." (CLG , 1975:95). É possível, ainda baseando-nos na obra saussuriana, estabelecer importantes relações no quadro geral da Ciências Humanas e Sociais. Observando o conceito de valor na Lingüística e na Economia, constatamos que, sob o enfoque lingüístico, "os dados naturais não têm nenhum lugar" (CLG , 1975:96); e, num enfoque econômico, ao contrário, é preciso entender que um valor tem raiz nas coisas e em suas relações naturais e dimensionar esse valor no tempo exige levar em conta que ele depende de um sistema de valores contemporâneo.

Na História do Pensamento Econômico, desde autores do século XVIII a autores do século XX, desde Quesnay e suas propostas a respeito das sociedades governadas por leis naturais e 0 valor vinculado à terra até Samuelson e Milton Friedman e o valor em função da utilidade: todos levam em conta a dependência de um outro sistema contemporâneo aos sujeitos que assumem tais valores.

Há, dessa forma, dois enfoques:

- um lingüístico, no qual os valores são construídos por intermédio de mecanismos próprios da língua;

- e um enfoque econômico, que determina os valores em função das relações que os objetos comportam na história.

A Lingüística, sob o ângulo saussuriano, desvincular os signos dos dados naturais princípio do signo lingǘstico como imotivado, mais tarde repensado pela Semiótica nos problemas de referencialização e intersemioticidade (Greimas e Courtés, 1983:378). Saussure ressalta, também, a necessidade de se distinguir uma Lingǘstica sincrônica e uma Lingüística diacrônica, embora estabeleça o vínculo indissolúvel entre as duas perspectivas.

A partir desses fatores constitutivos dos valores, Saussure estabelece a noção de valor como identidade:

...nos sistemas semiológicos, como a língua, nos quais os elementos se mantêm reciprocamente em equilíbrio, de acordo com regras determinadas, 
a noção de identidade se confunde com a noção de valor, e reciprocamente. (CLG, 1975:128).

Essa noção de valor como identidade é destacada quando o autor chama a atenção para que se faça a distinção entre valor e significação, ressaltando que, se tal distinção não for efetuada, corre-se o risco de reduzir a língua a uma simples nomenclatura. Uma língua é muito mais que uma forma de dar nome às coisas. A língua é um sistema:

a língua é um sistema em que todos os termos são solidários e o valor de um resulta tão somente da presença simultânea de outros... (1975:134).

Essa forma de compreender a língua tem com primeira conseqüências colocar o signo lingüístico como uma grandeza, cuja dimensão de valor pode ser formulada seguindo princípios gerais. Assim, há dois princípios básicos para a constituição do valor: a) comparação com um objeto "dessemelhante", cuja troca implica determinar o valor desse outro objeto; b) comparação com um objeto "semelhante", cuja comparação já é possível de ser efetuada. Saussure explica esses princípios da seguinte forma:

uma palavra pode ser trocada por algo dessemelhante: uma idéia; além disso, pode ser comparada com algo da mesma natureza: uma outra palavra. Seu valor não está então fixado enquanto nos limitamos a comprovar que pode ser 'trocada' por este ou aquele conceito, isto é, que tem essa ou aquela significação; falta ainda compará-la com os valores semelhantes, com as palavras que se lhe podem opor. Seu conteúdo só é verdadeiramente determinado pelo concurso do que existe fora dela. Fazendo parte de um sistema, está revestida não só de uma significação como também, e sobretudo, de um valor, e isso é uma coisa muito diferente (...). Assim, 0 valor de qualquer termo que seja está determinado por aquilo que o rodeia... (CLG , 1975:134-5)

Pode-se, então, perceber que para Saussure valor é identidade e essa identidade, na concepção lingüística do termo, só é possível de ser compreendida pela diferença - "na língua só existem diferenças" (CLG, 1975:139). É precisamente a identidade compreendida a partir das diferenças que estabelece um jogo de trocas, no qual se torna possível dimensionar o valor do signo. Assim, é esse jogo de comparações que vai além da significação e estabelece o valor:

Quando se diz que os valores correspondem a conceitos, subentende-se que são puramente diferenciais, definidos não positivamente por seu conteúdo, mas negativamente por suas relações com os outros termos do sistema. Sua característica mais exata é ser o que os outros não são. (CLG , 1975:136). 
O valor como identidade e diferença pode ser compreendido, de acordo com o que nos esclarece Edward Lopes (1997:120), tendo em vista a clássica dicotomia saussuriana - língua e fala: a língua, social, abstrata, sistêmica; e a fala, individual, concreta, o processo.

As identidades são estabelecidas no nível do sistema (da língua); na fala, no processo, as unidades de identidade do sistema manifestam-se graças às suas diferenças. Assim, os elementos da fala projetam uma descontinuidade sobre a continuidade sistêmica. A assunção dos valores sistêmicos é concretizada quando o falante, dotado de sua competência semiótica, realiza as substituições partindo das associações paradigmáticas. Tendo como base as continuidades associativas do paradigma, o falante projeta 0 caráter diferencial inerente à própria rede de equivalências, de identidades, efetua escolhas e assume a assunção das diferenças: transforma identidades em diferenças, projetando-as por meio das combinações sintagmáticas.

A assunção dos valores é a assunção das diferenças intrínsecas às determinações semânticas elementares do lexema. Se observarmos, por exemplo, o paradigma formado por "menino", "guri", "garoto" e "rapazola", encontramos as continuidades associativas, as identidades paradigmáticas. Quando há a escolha de um dos termos, há, simultaneamente, a projeção das diferenças existentes entre os elementos do paradigma que propiciam a própria opção do falante. D essa forma, projetam-se na massa potencializada de identidades contínuas, as descontinuidades provenientes das diferenças, as quais possibilitam a escolha do termo que será concretizado na fala, domínio das associações sintagmáticas. Trata-se, portanto, das identidades que só se tornam compreensíveis por meio das diferenças.

As identidades e diferenças constitutivas das determinações semânticas elementares são características capazes de gerar continuidades e descontinuidades que acompanham todo 0 percurso de construção do sentido e essas identidades e diferenças só podem ser definidas a partir das comparações, das equivalências fixadas entre os termos.

Nota-se, mais uma vez, o caráter de comparação que o valor assume. É na própria definição saussuriana que estamos diante da comparação e do sentido de equivalência intrínseco ao valor. Assim, não há um valor absoluto, que tem existência em si mesmo: 0 valor é sempre fruto das relações de equivalência que o signo carrega. É justamente a comparação que possibilita estabelecer as relações de equivalência; e isto vai levar aos mecanismos de troca. 
A contribuição de Saussure, ao propor o valor como identidades e diferenças fundamentadas em um sistema de equivalências, está presente na Semiótica desde Semântica E strutural (Greimas, 1976) e D u Sens (G reimas, 1970), até D u Sens II (G reimas, 1983) - obras que constituem a base da Semiótica Narrativa. Semântica E strutural e Du Sens (1970) mostram as determinações da semântica elementar constituídas como oposições. Nessas obras, o quadrado semiótico da sintaxe fundamental, baseado em contrários e contraditórios, opera a determinação semântica elementar, ou seja, transpõe para as articulações lógico-conceptuais os fundamentos de identidade e diferença já expostos no C urso de L ingüística G eral. Já em D u Sens II (1983), temos, no artigo "Un problème de sémiotique narrative: les objets de valeur", a narrativa como circulação de valores, pois é ela que gera mecanismos de troca entre os sujeitos. Essa troca, própria das articulações narrativas, já está fundada em Saussure.

O sistema de equivalências, constitutivo das determinações elementares do sentido, determina um campo Esse campo de equivalências traz consigo o jogo de identidades e diferenças - sem o qual seria impossível estabelecer as relações lógicas de contradição e contrariedade - e essas identidades e diferenças são propostas já consagradas pelo Mestre de Genebra. São as identidades e diferenças próprias do campo de equivalências, situadas no nível mais profundos da significação, que irão compor uma massa potencializada capaz de sustentar os mecanismos de troca que serão delimitados na circulação dos valores traçada pela narrativa.

Do ponto de vista da semântica fundamental não há nas relações de significação mais do que relações de equivalência estabelecidas a partir de identidades e diferenças. Ter em vista a concepção lingǘstica do valor como a que determina o caráter intrínseco ao signo de comparação, de relações em um sistema de equivalência estabelecendo identidades e diferenças, é fundamental para a compreensão do valor na Semiótica Narrativa e D iscursiva.

\section{Paradigma antropológico - o eixo das trocas}

O paradigma lingüístico da construção do conceito de valor compõe um campo de equivalências sobre 0 qual vão sendo construídas as identidades e diferenças, as quais atuam de forma a assegurar a primeira formalização dos investimentos semânticos elementares. A partir desse campo potencializado de forças de significação, há a projeção dos investimentos semânticos discretizados nas descontinuidades narrativas. A massa sêmica desses investimentos semânticos elementares é então assumida pelos dois pólos fundamentais do jogo sintático, - 
responsáveis pelas transformações narrativas e pelo movimento discursivo: sujeito e objeto. Graças à presença do sujeito e do objeto, o campo de equivalências torna-se palco de trocas.

D essa forma, as articulações narrativas estabelecem um outro paradigma da construção do conceito de valor, um paradigma marcado pela concepção antropológica. É, precisamente, no nível da narrativa que o valor ganha seus dois grandes protagonistas: sujeito e objeto. É no nível da narrativa que o valor assume a forma de conceito semiótico, pois as significações vão se constituindo a partir das relações. 0 campo sígnico, dos investimentos sêmicos elementares, passa a ser atualizado por meio das relações estabelecidas pelos protagonistas da narrativa.

Numa perspectiva diacrônica, é possível apontar dois momentos nos estudos sobre a narrativa. 0 primeiro marcado pela concepção antropológica baseada no privilégio do sujeito; e 0 segundo, fruto do desenvolvimento dessa concepção. Caminha-se, pois, em direção a uma Semiótica que deixa de assumir o fazer como modalidade fundadora e passa a considerar o ser e a dimensão patêmica como também propulsoras das transformações narrativas.

De acordo com esse percurso, a concepção antropológica do valor pede, inicialmente, que se retome a Semiótica dos anos setenta, com seus trabalhos voltados para as propostas das bases teóricas da narrativa.

A concepção antropológica impõe, com privilégios, a presença do sujeito: é o sujeito do fazer alterando o sujeito de estado. Entretanto, a partir do final dos anos oitenta, os estudos da narrativa são ampliados e esse enfoque que dá privilégio ao sujeito é também revisto, de modo a aprofundar a análise das relações entre sujeito e objeto. 0 estudo do valor como produto da narratividade ganha análises mais elaboradas e busca-se a compreensão dos mecanismos de construção do valor a partir das metamorfoses do objeto (Assis da Silva, 1995:77-95).

0 texto de Greimas "Un problème de sémiotique narrative: les objets de valeur", presente no livro D u Sens II (1983), é essencial para a compreensão da dimensão da narrativa como responsável pela produção do valor. Há, no texto de G reimas, questões decisivas para a conceituação do valor: uma delas é a que determina o valor como uma função estabelecida a partir da relação de junção. Isto é vital não só para a concepção antropológica, mas para a própria concepção do valor no quadro geral das Ciências Sociais.

A unidade mínima da narrativa é o enunciado elementar, que é definido como uma relação-função de transitividade entre dois elementos. Sujeito e objeto são elementos colocados 
nessa relação transitiva, nessa relação de desejo, são elementos que se interdefinem, são funtivos de uma mesma função. Pode-se distinguir dois tipos de enunciados elementares: enunciado de estado - do ser - e o enunciado do fazer.

O enunciado de estado estabelece uma relação juntiva (conjunção ou disjunção) entre sujeito de estado, o sujeito do ser, e objeto. É a partir desta relação que o objeto passa a estar investido de valor.

O outro tipo de enunciado é o enunciado do fazer. 0 sujeito do fazer altera a relação do sujeito de estado com o objeto de valor. É uma relação de transformação, na qual um sujeito operador exerce um fazer transformador, alterando o estado de junção. 0 enunciado do fazer é a representação de um ato produtor de estado. Sendo assim, a narrativa aparece como um percurso entre conjunções e disjunções, ou vice-versa, operado por meio de transformações.

Greimas indica de forma precisa a junção como uma "catégorie sémique, s'articule en deux termes contradictoires, conjonction e disjonction, donnant ainsi lieu à deux types d'énonoés d'etat:

$$
\begin{aligned}
& \text { Énoncés conjonctifs }=\mathrm{S} \cap \mathrm{O} \\
& \text { Énoncés disjonctifs }=\mathrm{S} \cup \mathrm{O} \quad \text { (Greimas, 1983:28) }
\end{aligned}
$$

É por intermédio da função estabelecida pela relação juntiva que se inscreve 0 valor no enunciado de estado. Sujeito e objeto só podem ser definidos um em relação ao outro. Esta relação garante a existência semiótica dos termos e, concomitantemente, estabelece 0 valor. Antes da junção, o sujeito é virtual - um proto-sujeito, como afirma Greimas (Greimas e Fontanille, 1993:30-4) - e o objeto ainda não adquiriu seu estatuto de objeto de valor. Só a junção dá a esse termo - o objeto - 0 estatuto de valor. Sujeito e objeto são investimentos sêmicos discretizados a partir das relações de identidade e diferenças; só a junção, o elo estabelecido pelo desejo, é que atualiza o sujeito e o objeto e, conseqüentemente, estabelece o valor. Mesmo a relação de disjunção não significa a ausência de relação, pelo contrário, é um modo de existência do sujeito e do objeto de valor. A disjunção não é a ausência de relação, mas sim uma forma possível, uma forma de relação diferente da conjunção. 
O utro aspecto importante que está no citado texto de G reimas é referente ao conceito de solidariedade. Este é um outro ponto fundamental que terá conseqüências para 0 desenvolvimento das pesquisas posteriores da Teoria Semiótica.

A análise do conceito de solidariedade parte da pressuposição recíproca entre um enunciado conjuntivo e um disjuntivo, porque se um sujeito 'S1' está em conjunção com um objeto ' $\mathrm{O}$ ', há necessariamente a disjunção deste objeto 'O' em relação a um sujeito 'S2':

Nous proposons donc désigner du nom de jonction paradigmatique la concomitance logiquement nécessaire de deux énoncés de conjonction et de disjonction, affectant deux sujets distincts. (G reimas, 1983:34).

Compreende-se, então, que a narratividade pressupõe um encaixe de estados narrativos, pois um enunciado conjuntivo tem necessariamente a presença de um sujeito transformador que operou uma transformação neste mesmo enunciado, anteriormente disjuntivo com relação a esse sujeito de estado. Essa seqüência de estados narrativos, essa solidariedade dá à junção um caráter, também, sintagmático. Há, portanto, na narrativa a manifestação dessa "double nature syntagmatique et paradigmatique, jouant simultanément sur les deux types de discontinuités." (G reimas, 1983:35).

A narrativa traz a marca das descontinuidades, pois no percurso narrativo são firmados e rompidos contratos e, assim, as transformações vão ocorrendo. Trata-se de um encaixe de programas narrativos (PN). O programa narrativo é um sintagma que comporta uma mudança de estado efetuada por um sujeito em busca da alteração da junção com o objeto. Os vários programas que a narrativa comporta são articulados em função de um programa principal (PN de base); e essa articulação de programas determina um dado percurso: o percurso narrativo. 0 valor é dimensionado como produto da narrativa, como construído por meio do percurso narrativo. Trata-se da busca efetuada pelo sujeito, de seu movimento perseguindo o objeto de valor do principal programa narrativo - o programa narrativo de base. É a relação de busca que produz 0 valor. $O$ valor é arquitetado na narrativa de maneira dinâmica e debreado, projetado, no discurso. A narrativa é, então, uma seqüência de transformações que vão sendo articuladas e, assim, produzem um objeto de valor. Há, neste percurso, a construção de valores que podem ser chamados de intermediários, os quais permitem chegar ao valor almejado: 0 valor contido no programa narrativo de base. 
O bserva-se que conceitos-chaves da Teoria Semiótica - junção, solidariedade, natureza paradigmática e sintagmática - já estão aqui traçados, mas nota-se que os trabalhos ainda concentram a atenção no sujeito. 0 sujeito é, até então, o protagonista das articulações narrativas, mesmo levando-se em conta que sua própria definição é fundada numa relação. Exatamente para que seja garantida a coerência conceitual do modelo, isto é, para manter 0 sujeito como protagonista e, concomitantemente, respeitá-lo como definido a partir de uma relação-função, é que o objeto é compreendido como uma casa sintática, um espaço de relação, um meio pelo qual o sujeito vai relacionar-se com os valores. Trata-se do espaço em que estão fixados os desejos do sujeito; por isso, um mesmo objeto pode aparecer com valores diferentes para sujeitos diferentes. Os valores dependem da cultura, da sociedade. É por se tratar de uma concepção de valor, na qual há a circulação de valores em função do contexto sócio-cultural, que se pode chama-lá de concepção antropológica.

Verifica-se, então, que o próprio desenvolvimento da concepção antropológica vai originar a necessidade de redimensionar os conceitos por ela estabelecidos. É o que começa a acontecer quando aparecem os estudos sociossemióticos e a ênfase é dada a um outro modo de presença do sujeito na narrativa: a presença do sujeito-destinador. São trabalhos, entre outros, de Landowski (1991), Bertrand (1987), todos eles delimitando uma maneira de compreensão da narrativa, na qual o sujeito passa a comportar uma dimensão coletiva e, além disso, compartilha a responsabilidade das transformações narrativas com o destinador.

Greimas em Semiótica e Ciências Sociais (1981) já indica as bases por meio das quais é possível desenvolver uma perspectiva sociossemiótica. Essa perspectiva, como já dissemos, vai se firmando, em princípio com os estudos voltados para a narratividade, e os problemas relativos ao destinador começam a ser destacados. Isto porque, numa perspectiva que enfoca as interações sociais, aquele que impulsiona, aquele que faz-fazer o sujeito, aquele que funda o sujeito como ser social, que manipula e sanciona os sujeitos, pode ser considerado como o verdadeiro protagonista da cena pública. Torna-se necessário, então, situá-lo numa perspectiva macrossocial, ampliando a concepção e considerando-o não só como aquele que faz-fazer o sujeito, mas como aquele que faz-fazer os sujeitos, como aquele que funda e sanciona a performance referente às interações sociais. Sendo assim, o destinador assume a responsabilidade de fonte de valor; e 0 jogo das interações sociais passa a constituir um jogo fundamentado nas buscas e perdas de valores. 
A busca e a perda de valores se configura como um percurso à procura de objetos, objetos que comportam os valores. Os objetos permitem que o sujeito tenha acesso aos valores. Assim, o objeto não é reconhecido por si mesmo, mas sim por suas determinações; essas determinações só podem ser apreendidas como diferenças - nota-se aí, mais uma vez, a presença da conceituação saussuriana no que diz respeito à apreensão da identidade a partir das diferenças. É a característica diferencial que lhe confere seu caráter de valor semiótico; sendo assim, o objeto vai aparecer como suporte para os valores, como o lugar de reunião das determinações de valores, e só o encadeamento sintático é capaz de fazer com que ele e os valores nele investidos possam ser identificados.

Nota-se, nesse estágio do modelo, que o objeto é um conceito sintático, um termoresultante proveniente da relação do homem com o mundo. Um termo do enunciado elementar que vai, junto com o sujeito, fazer com que esse enunciado indique "un simulacre sémiotique représentant, sous la forme d'un spectacle, cette relation au monde" (G reimas, 1983:23).

Nesta perspectiva, é possível falar de valor realizado para o valor que se acha investido num objeto em conjunção com o sujeito, e falar em valor virtual para aquele que está investido num objeto em disjunção com o sujeito. A narrativa é confirmada, mais uma vez, como um encadeamento sintagmático de realizações e virtualizações, no qual um sujeito realizado deve ser primeiramente instaurado como um sujeito virtual.

Tomando como base essa concepção proposta pela Semiótica, percebe-se que é inadequado falar em valores achados ou perdidos. Achar um objeto, no sentido semiótico do termo, é apreendê-lo como valor, estabelecendo uma relação primeira com o sujeito. Entretanto, a relação juntiva entre sujeito e objeto só pode ser alcançada por meio de uma construção que tem início com as formalizações mínimas do campo semântico elementar. Os objetos, portanto, não podem aparecer sem explicação - como se antes não possuíssem nenhuma relação com o sujeito - e entrar, sem uma virtualização anterior, em conjunção com um enunciado de estado.

De forma correlata, perder um objeto é abolir todas as relações com ele estabelecidas e, por isso mesmo, destruir o próprio estatuto semiótico do sujeito. São casos extremos de surgimento e desaparecimento de valor que encobrem um universo imanente de valores. Greimas esclarece esse tipo de relação propondo que: 
...à l'intérieur d'un univers axiologique donné, les valeurs circulaient en vase clos et que les apparences de trouver et de perdre recouvraient en réalité les conjonctions e les disjonctions absolues par lesquelles cet univers immanent communique avec un univers transœendant, source et dépositaire des valeurs hors circuit. (1983:30).

Esse mecanismo explica o jogo existente nas chamadas "sociedades fechadas", nas quais as riquezas são disponíveis em "quantidades limitadas". A circulação dessas riquezas acontece num "circuito fechado", e o percurso sintático desses valores se desenvolve de maneira que a cada aquisição efetuada por um membro da sociedade corresponde necessariamente uma perda por um outro membro dessa mesma comunidade.

D essa forma, aos valores "legais", considerados como provenientes do resultado de um trabalho, opõem-se os valores "ilícitos" - a "riqueza achada" - entendidos como valores negativos e revelando um "anti-universo axiológico". Os personagens que "acham" esses valores podem ser tomados como mediadores entre um universo transcendente e um universo imanente, fonte de novos valores passíveis de serem colocados em circulação.

Ainda com relação à circulação de valores, um aspecto também importante é a questão da troca. Pode-se destacar dois tipos de troca: uma troca virtual e uma troca realizada. A estrutura da troca exige a presença de dois objetos de valor (0 1 e 02 ) e dois sujeitos ( $\mathrm{S} 1$ e S2), e é possível considerá-la como uma dupla transformação operada, concomitantemente, em dois enunciados juntivos distintos por dois sujeitos do fazer.

A troca virtual é aquela na qual os sujeitos ainda se sentem atraídos pelos objetos a que irão renunciar. Os objetos que serão trocados ainda permanecem como objetos de valor para os sujeitos que irão renunciá-los. Dessa forma, esses sujeitos são, ao mesmo tempo, virtuais e realizados. Por outro lado, a troca realizada é aquela que acontece de maneira total, ou melhor, a partir da troca (transformação) o objeto renunciado deixa de ser considerado como um objeto de valor para o sujeito que a ele renunciou; há a renúncia cognitiva do valor.

A circulação de valores por meio do percurso narrativo indica uma Semiótica da Troca. Os conceitos de troca virtual e troca realizada são decisivos para que se compreendam as relações interdiscursivas e intertextuais no quadro das Ciências Sociais. É preciso frisar que, mesmo um modelo semiótico que esteja ainda dentro dos limites da narrativa e das propostas embasadas nas dimensões dos estudos desenvolvidos até os anos setenta, sem levar em conta as conquistas do enfoque tímico-tensivo, obtidas principalmente a partir dos anos noventa, mesmo 
esse modelo já se mostra como um instrumental valioso para a análise de questões importantes como a questão do mercado - no quadro geral das Ciências Humanas e Sociais. 0 mercado, protagonista absoluto dos textos das Ciências que se preocupam como o mundo do capital, sob 0 ângulo semiolingǘstico, é apenas o palco de um percurso, uma realização narrativa, um jogo, um encadeamento complexo de programas de troca envolvendo inúmeros sujeitos, portadores de inúmeros papéis actanciais - destinadores, sujeitos manipulados, e outros.

No entanto, a construção discursiva do mercado nas sociedades do capitalismo monetário o faz parecer um destinador potente, um grande sujeito do programa narrativo de base, isto é, aquele sujeito do fazer responsável por todo o movimento de todas as narrativas subjacentes a todos os textos produzidos pela vida cotidiana. Esse grande sujeito, porém, não passa, ele mesmo, de um encadeamento complexo de programas de troca. Trata-se do mais impessoal dos sujeitos, pois, em sua gênese, não tem estatuto do ser, é um movimento executado por meio do fazer. Trata-se da metamorfose do fazer no ser, emprestando ao simples movimento uma dimensão ontológica.

Mais uma vez, é possível aqui perceber por que essa concepção é chamada de concepção antropológica e está vinculada a uma Semiótica da Troca. Trata-se também de uma concepção que dá destaque à leitura sociopolítica, na qual valor é aquilo que se troca; é uma forma pragmática, concreta, de se tratar 0 valor. A narratividade estabelece a circulação e a comunicação de valores; as transformações narrativas são, também, transferência de valor. Essa Semiótica da Troca, cujo enfoque na narratividade tanto favorece a compreensão de questões fundamentais no quadro das Ciências Humanas, a partir dos anos noventa, recebe contribuições importantes de trabalhos que já comportam uma outra visão sobre a relação entre sujeito e objeto.

Nota-se, assim, que o trabalho em Semiótica requer uma visão abrangente, capaz de perceber a Teoria Semiótica como totalidade, como uma rede de conceitos que têm uma interdefinição recíproca. Não é possível avançar em um dos aspectos sem que isto não interfira na rede conceitual como um todo. É por esse motivo que as conquistas localizadas preponderantemente no paradigma tímico-tensivo contaminam também o paradigma antropológico e isto é muito significativo para o entendimento dos textos produzidos pelo mercado. 
D o ponto de vista diacrônico, a concepção da narrativa que tem o sujeito como centro das investigações ainda não imprime uma visão genuinamente subjetiva ao modelo, pois, apesar de tratar-se do sujeito, este não é privilegiado do ponto de vista de sua carga tímico-tensiva individual. É ainda uma semiótica do fazer que rege as transformações narrativas. 0 fazer do sujeito pode até estar sobredeterminado por uma carga tímico-tensiva, mas não é essa carga, própria do ser, interoceptiva, que vai ser responsável pelo ato. É o fazer, e não 0 ser, que impulsiona a narrativa. Utilizamos aqui, na exposição sobre a Semiótica da Troca e as questões do mercado, referências à modalização do ser, porém esse tipo de análise será aprofundada pela própria Teoria Semiótica com conceitos e outras abordagens propostos, a partir de 1987, com a publicação de D a Imperfeição (G reimas, 2002).

A aspectualização, própria do campo discursivo, impõe um ponto de vista sensibilizado, um olhar que sensibiliza o percurso narrativo, e isto já aparece na Teoria Semiótica dos anos oitenta, mas não há ainda o aprofundamento necessário. A Semiótica Narrativa dos anos setenta e começo dos anos oitenta, de certo modo, dá pouca ênfase às paixões. A partir do final dos anos oitenta, há novas preocupações e as análises emprestam uma sensibilidade, até mesmo, ao objeto. A narrativa dos anos setenta, quando trata das paixões, ainda está presa ao modal e ao actancial, não chega a aprofundar as aspectualizações e a sensibilização que são privilegiadas quando se leva em conta um estudo mais completo das sobredeterminações tímico-tensivas.

É este ponto de vista que vai ser alterado no final dos anos oitenta com a publicação da obra de Greimas D a Imperfeição (2002). G reimas propõe um outro olhar para a narrativa, a partir do qual o objeto deixa de ser apenas um suporte. Há, para isso, a necessária contaminação da narrativa pelo campo discursivo e pela massa sêmica polarizada do campo das equivalências. A seqüência de níveis passa a ser compreendida não mais como uma série de etapas sucessivas, mas como uma inter-relação dinâmica entre campos - o campo fundamental e o campo discursivo os quais envolvem um eixo que os sustenta: a narratividade.

No livro D a Imperfeccão Greimas (2002:29) nos mostra como a figura de uma gota - um objeto - apropria-se gramaticalmente das funções do sujeito e transforma-se em um ator modalizado e patêmico. Apresenta-nos a narrativização do comportamento de uma gota, isto é, enfoca a narrativa não mais do ponto de vista do sujeito, não mais tendo o sujeito como protagonista absoluto. Esta análise é um marco nos estudos da narratividade e altera o paradigma antropológico do conceito de valor. Cabe destacar mais uma vez que os níveis de análise 
propostos pela Semiótica não são compartimentos isolados, formam uma rede de relações sem a qual não se pode dimensionar a construção da significação.

Greimas prossegue em D a Imperfeição (2002:29-30) indicando- nos de que forma a construção do sujeito e do objeto acontece graças à relação que se desenvolve entre eles. Tudo acontece como se o conceito de junção - de função - fosse levado às últimas conseqüências. Partindo desse quadro, Assis da Silva (1995:77-87) chama a atenção para a necessidade de um enfoque da narrativa que dê também privilégios para a construção do objeto, um enfoque que aponte um percurso mostrando "as operações práticas envolvidas na construção do objeto e na sua transformação em objeto de valor" (Assis da Silva, 1995:77); Este autor propõe olhar 0 objeto além de uma "casa sintática", para isto elabora um estudo que tem como ponto inicial 0 trabalho de Bastide (1987) - Le Traitement de la Matière -, o qual parte de um paralelo entre a construção do sujeito e a construção do objeto para detectar as transformações que possibilitam chegar ao valor.

Insistimos que um dos pontos que merecem ser destacados nesta abordagem é aquele que marca uma evolução - o movimento diacrônico no interior do próprio. Há agora destaque para dois aspectos: o primeiro indica a figuratividade começando a ser delimitada desde o campo das significações elementares como uma figuratividade profunda, ou seja, demarcada a partir das identidades e diferenças formalizadas nas articulações mínimas de sentido. 0 segundo aspecto refere-se às articulações modo-passionais chamando a atenção para os efeitos passionais do ser no campo que era antes domínio absoluto do fazer.

A narratividade aparece como irremediavelmente impregnada pelas determinações do campo semântico fundamental e do campo discursivo, funcionando como uma linha descontínua envolvida por esses dois campos. No entanto, o que importa, apesar de todo esse envolvimento com as forças de outros campos, são as transformações, as descontinuidades narrativas que permanecem preservadas: 0 eixo de sustentação da construção do sentido permanece.

Assis da Silva (1995:79) expõe que se trata das "operações sintáticas subjacentes a uma metamorfose" 0 autor mostra uma combinatória hierarquizada de transformações da matéria preferimos aqui retomar a expressão hjelmsleviana e chamar de transformações hierarquizadas da substância --, substância essa própria do objeto. 0 objeto comporta uma sintaxe de construção das formas. É importante sublinhar que se trata ainda do domínio narrativo, do domínio das transformações narrativas, são "fazeres múltiplos" que podem ser reduzidos a algumas categorias 
invariantes por meio de operações elementares. A primeira categoria refere-se à oposição amorfo/ estruturado e indica a operação de estruturação. A outra operação importante é a briolagem: "a criação de objetos-valores novos não opera com objetos prontos, perfeitos, acabados, cuja combinação produziria o objeto novo; opera com fragmentos, estilhaços, lascas de objetos" (Assis da Silva, 1995:79).

A operação da briolagem, descrita por Bastide e retomada por Assis da Silva, é uma operação fundamental na construção dos objetos de valor nas sociedades capitalistas globalizadas. Este tipo de procedimento já havia sido apontado por Barthes (1987:131-178) de uma maneira mais radical quando este autor nos apresenta as mitologias do mundo do mercado como uma forma parasita que deforma, rouba, fragmenta e restitui a história impondo um novo valor, um valor de equivalência. Para Barthes, é como se o campo das equivalências elementares fosse projetado no discurso de forma a privilegiar as identidades em prejuízo das diferenças. Este roubo, esta fragmentação e esta restituição, pertinentes à composição das mitologias, nada mais é que uma bricolagem: não existem substâncias virgens, situadas em seu grau zero, nas quais seriam operadas transformações; ao contrário, as matérias sofrem metamorfoses. Os "fazeres múltiplos" operados pelos pequenos sujeitos do mercado partem da história e a estruturam a partir das significações fragmentadas. Os mitos não surgem do nada, são montados a partir da fragmentação das necessidades, da decomposição e recomposição daqueles objetos que já haviam ocupado o lugar de objeto de valor.

Há, confirmando não apenas a posição de Assis da Silva (1995:80), mas indo também ao encontro das proposta de Levi-Strauss (1971) sobre as mitologias, a composição do mito como aquela que se faz sobre a fragmentação dos objetos já existentes. Assim, o mito nos textos produzidos pelo mercado pode ser compreendido como um objeto de valor construído por meio da briolagem executada por agentes, por inúmeros pequenos sujeitos cujo fazer tem o desejo fundado por um outro sujeito muito mais potente. São "operações sintáticas subjacentes à metamorfose" dos objetos que passam a ter um papel decisivo nas mitologias do mercado.

Dessa forma, desloca-se o ponto de vista que enfoca com privilégios o sujeito, para que se preste atenção nas operações que levam às metamorfoses que ocorrem na construção do objeto. Propõe-se um novo ângulo: uma análise da sintaxe das formas que envolve, simultaneamente, sujeito e objeto. Neste ponto é preciso lembrar Greimas nos alertava para 0 modo como o objeto se apropria gramaticalmente do sujeito e passa a comportar o "estatuto de 
ator modalizado e patêmico". Esta é exatamente a construção sintático-semântica que o mercado opera não apenas na construção do objeto de valor, mas em sua própria construção como sujeito.

O mercado, o palco das trocas, torna-se o palco de uma série de transformações efetuadas por meio dos fazeres múltiplos que os inúmeros sujeitos que compõem o percurso executam. Esses fazeres múltiplos são operações elementares - a estruturação, a triagem, a mistura, a bricolagem. Essas operações constroem um objeto dotado de valor, a partir de substratos "desprovidos de tais valores ou que possuem um valor que não tem nada a ver com 0 objeto resultante."(Assis da Silva,1995:83).

Na construção do objeto de valor há, concomitantemente, a própria construção dos sujeitos responsáveis pelos fazeres narrativos e, o mais importante, há a construção do grande sujeito, o mercado. Nas descontinuidades do percurso narrativo, as metamorfoses vão ocorrendo não apenas com 0 objeto e com o sujeito, mas o próprio percurso adquire uma outra forma e passa a constituir- se como um sujeito. Nesta sintaxe de construção das formas, o percurso - 0 encadeamento de programas - sofre uma nova estruturação, sofre metamorfoses e toma 0 estatuto de controlador das paixões, de destinador: 0 palco renasce como mercado e constitui-se como grande sujeito.

Um percurso narrativo, um encadeamento de programas narrativos, uma articulação sintática, cristaliza-se como uma potente categoria semântica. Há uma projeção inversa daquela apontada por Jakobson (1975:130) na poética. Não é o princípio da equivalência das categorias paradigmáticas que é projetado nas combinações sintáticas do sintagma; mas um sintagma que é cristalizado como categoria assumindo uma dimensão semântica roubada e restituída.

Os sujeitos que executam os fazeres múltiplos implícitos nas operações elementares têm existência em função das relações que se estabelecem nesse grande percurso de trocas e circulação de valores. Um percurso de trocas que esvaziou e roubou a pulsão dos sujeitos e passa a ter existência patêmica: "o mercado está sensível”, "o mercado sentiu”, "o mercado sofreu”, "0 mercado reclamou". O mercado pulsa. Entretanto, se, por um lado, o mercado pulsa, por outro lado, a pessoa se fragmenta e o indivíduo se esfacela. A bricolagem que compõe os processos narrativos acaba por se refletir nos sujeitos, nas pessoas, nas interações da vida cotidiana. É como se as aspectualizações discursivas invadissem as transformações narrativas operadas pelo jogo sintático do mercado. 
Trata-se das metamorfoses, da sintaxe narrativa de construção do objeto sensível e de construção do sujeito-mercado. 0 que em princípio poderia ser considerado como um discurso subjetivo, compondo um conceito subjetivo, é um discurso que tem uma subjetividade esvaziada, pois não há uma presença patêmica, há uma falsa presença ontológica. 0 sujeito está esvaziado. É um sujeito cuja força do desejo é exercida bem mais pelo objeto do que por ele próprio. 0 objeto está mais potencializado, deixou de ser apenas uma casa sintática, tornou-se agora sujeito e apropriou-se da modalização do ser, é agora o agente fundador das tensões.

A construção narrativa do conceito do discurso mercantil fixa um movimento sintático, fixa um ponto de vista, uma aspectualização, mas quem instala o ponto de vista é um sujeito cujo desejo está esvaziado. Fixa-se o papel decisivo da demanda, porém é a intensidade do objeto que vai realmente direcionar a procura, a demanda, o consumo. Tudo sempre em função de um grande sujeito, o mercado.

A carga semântica que determina qual a figuratividade profunda e qual a figuratividade de superfície que dará a face ao sujeito e ao objeto é moldada pelo mercado e não pelos sujeitos segundos que operam os fazeres múltiplos. Estes já estão com seus desejos individuais transformados em necessidades e transferidos para o objeto.

As análises sobre a narrativa são fundamentais para a compreensão do valor, exatamente por tratarem do conceito de troca, da circulação de valores e, sobretudo, das relações entre sujeito e objeto. É a partir do entendimento da troca e das relações entre sujeito e objeto nos discursos das Ciências Sociais que é possível ler o conceito de valor nas sociedades de mercado.

A troca é um produto da narrativa e exige a presença do sujeito. É preciso, então, questionar esse sujeito, seu estatuto sintático-semântico. Nossa análise aqui é antropológica. Estamos discutindo o paradigma antropológico do conceito de valor. É neste paradigma que 0 campo das equivalências realiza-se, por meio das transformações narrativas, como palco das trocas e assim acaba por constituir um sujeito: 0 mercado.

Neste paradigma antropológico a discussão é sobre o sujeito, qual sua forma e qual é a sintaxe de construção dessa forma. Discutem-se quais são os tipos de sujeito que são construídos e quais são os estatutos sintático-semânticos desses sujeitos.

Trata-se da troca e dos sujeitos que operam a circulação de valores. Isto confere ao paradigma antropológico do conceito de valor a possibilidade de inúmeras relações 
interdiscursivas e intertextuais; pois o que se constata é que, seja na Economia ou em qualquer outro campo das Ciências Sociais, há movimentos sintáticos profundamente semelhantes: relações entre sujeitos e objetos, sujeitos em busca de objetos, ou objetos passionais atraindo o desejo dos sujeitos. São articulações sintáticas que sustentam inúmeros discursos relacionados à vida social.

\section{Paradigma tímico-tensivo - o campo das tensões}

Na composição semiolingüística do conceito de valor abordamos o paradigma lingüístico e 0 antropológico e cabe-nos agora abordar aquele que é responsável pelo componente sensível dos discursos. É possível, do ponto de vista diacrônico, estabelecer algumas balizas que nos auxiliam a compreender este paradigma tímico-tensivo do conceito de valor: 0 ensaio de Greimas publicado em 1983 em D u Sens II (1983:93-102) "De la modalisation de l'être"; a publicação em 1987 do livro Da Imperfeição (tradução em português de 2002); as propostas sobre valências elaboradas em 1991 na obra Semiótica das Paix ões (tradução em português de 1993); e a publicação, em 1986, de um conjunto de propostas de vários semioticistas reunidas por G reimas e Courtés no livro Sémiotique - D ictionnaire Raisonné de la Théorie du L angage (1989) - este último abrindo uma pluralidade de temas e enfoques no campo da Semiótica. Esses pontos mostram o início daquilo que Bertrand chama de concepção filosófica e que aqui preferimos analisar como paradigma tímico-tensivo do conceito semiolingǘstico de valor.

A discussão sobre essa concepção de valor que nasce no final da década de oitenta pede que sejam analisados vários aspectos envolvidos e em quais linhas de pesquisa este conceito sensível de valor aparece.

Observa-se que a década de noventa abre caminho para algumas linhas de pesquisa na Semiótica; entre elas a Gramática Tensiva, com trabalhos de pesquisadores como Fontanille e Zilberberg; os estudos sobre o gosto e as questões sobre estese e estética, traçando uma Gramática do Sensível; e um outro campo de pesquisa, esse talvez delineado de forma um pouco menos nítida, que se propõe a refletir sobre as relações entre intertextualidade e interdisciplinaridade.

Passaremos, então, a analisar este paradigma tímico-tensivo, situando as bases dessa abordagem e como esse enfoque do conceito de valor é concretizado nas diversas pesquisas que estão sendo desenvolvidas. 
Em primeiro lugar, é preciso analisar a categoria tímica, pois está aí a base do aspecto sensível do conceito de valor; para depois abordar aspectos da Gramática Tensiva, questões relativas à Gramática do Sensível e traçar, também, algumas relações envolvendo a intertextualidade e a interdiscursividade.

A partir da publicação de Da Imperfeicãa, como já mencionamos anteriormente, as pesquisas semióticas revêem uma série de fundamentos e 0 valor, definido com base na narrativa, isto é, como objeto de valor, adquire uma outra perspectiva.

Um outro marco importante para a dimensão sensível dos estudos semióticos surge em 1992 com a publicação da obra Semiótica das Paixões (1993). Desse momento em diante, 0 conceito de valor passa a ser compreendido considerando-se também as valências configuradas desde o campo fundamental. Assim, o estudo do valor assume outros componentes e, nesse percurso, a categoria tímica torna-se essencial para as pesquisas.

A categoria tímica é um dos pontos de partida para as propostas de Semiótica das Paixões (1993) sobre o valor e as valências. Neste texto, Greimas e Fontanille (p.13) mostram que os traços, as figuras, os objetos do mundo natural constituem um significante e se acham transformados, pelo efeito da percepção, em traços, figuras e objetos do significado. É pela mediação do corpo perceptivo que o mundo se transforma em sentido, que 0 mundo é semiotizado. Essa mediação do corpo é decisiva para a dimensão semiótica, pois acrescenta as categorias proprioceptivas que constituem o "perfume" tímico e sensível que possibilita a configuração das formas cognitivas.

O processo de homogeinização pelo corpo - com suas características tímicas e sensíveis é comum a todos os universos semióticos. As figuras do mundo só podem fazer sentido e, conseqüentemente, assumir valores, mediante a sensibilização que lhes impõe a mediação do corpo. Compreender essa mediação do corpo é compreender a tensidade fórica, essa précondição da significação que faz com que quase-sujeitos e quase-objetos estejam imersos na massa tímica não polarizada.

Entretanto, para que se possa entender todas as dimensões que essas afirmações de Greimas e Fontanille carregam, é preciso voltar a D u Sens II (1983), exatamente ao artigo “D e la modalisation de l'être". Nesta obra, G reimas começa a mudar os rumos de uma Semiótica preocupada com o fazer e aponta para as preocupações com o ser. 
Neste artigo, Greimas (p.93) nos explica que todo semantismo é susceptível de ser articulado, quando é compreendido como uma relação, e situado como um eixo semântico em uma categoria semântica que pode ser representada com a ajuda do quadrado semiótico. Uma categoria semântica pode ser axiologizada pela projeção, sobre o quadrado que a articula, da categoria tímica. Trata-se de uma categoria primitiva, dita proprioceptiva, com a ajuda da qual procuramos formular a maneira pela qual todo ser vivo, inserido num dado meio, sente-se, a si próprio, e reage a esse ambiente. Um ser vivo pode, então, ser considerado como um sistema de atrações e repulsões.

O quadrado e a categoria representam taxinomias que serão axiologizadas graças à projeção da categoria tímica. Dessa forma, os termos constituintes passam a axiologias, deixando de ser apenas termos descritivos.

Essas afirmações têm como conseqüência propostas de um outro ângulo para enfocar 0 que foi originalmente chamado por Saussure de sistema de equivalências e que chamamos aqui de campo de equivalências. Este campo está, agora, sendo compreendido como um campo de relações imerso na massa tímica, que o potencializa com forças de atrações e repulsões. As identidades e diferenças tomam a forma de articulações lógicas desenvolvidas a partir de relações de complementariedade, eixos de contrários e de contraditórios, impregnadas de uma carga sensível. Graças à massa tímica, às forças de atrações e repulsões, que o que pode ser considerado em Saussure como descritivo, passa a adquirir um caráter axiologizado e potencializado.

Nota-se ainda que é preciso sublinhar a questão referente às condições de existência dessa massa tímica, desse "sistema de atrações e repulsões": é necessário refletir se se trata de um sistema próprio do indivíduo ou da pessoa (Mauss,1974). Este parece ser um dos pontos decisivos que envolvem 0 valor e as possíveis correlações elaboradas a partir desse conceito no quadro das Ciências Humanas e Sociais.

O caminho a ser percorrido para que se chegue à resposta dessa questão nos é apontado pelo próprio Greimas (1994) em manuscritos que nos foram deixados. Há, nesses manuscritos, dois momentos em particular que trazem indicações de aspectos que devem ser levados em conta quando se observam as dimensões da categoria tímica. No primeiro texto (p.28), o autor nos diz que "non seulement nos 'âmes', mais aussi nos 'corps' se trouvent culturalisés et relativisés à l'intérieur d'une culture". No segundo (p.34), prossegue alertando para "le fait qu'il y 
a de bonnes et de mauvaises passions, de bons et mauvais caractères met en évidence l'existence de systèmes normatifs implicites, propres à une culture donnée". Assim, ficam aqui assinaladas as perspectivas para que o estudo da categoria tímica não se limite à solidão e às especificidades da individualidade, mas que se pense o modo de ser e estar do ser no mundo como algo configurado por meio de bases mais abrangentes, por meio de sistemas significantes traçados pela cultura, por dimensões macrossociais.

Cabe destacar que tanto nas pesquisas da G ramática Tensiva, quanto nos trabalhos da Gramática do Sensível, há a presença marcante da categoria tímica. Isto pode ser constatado tanto na afirmações de Landowski no artigo "Gosto se Discute" (Fiorin e Landowski, 1997:100), quanto nas palavras de Fontanille e Zilberberg encontradas nas páginas de $\mathrm{G}$ rammaire Tensive (1996b:5).

No primeiro texto, Landowski mostra:

...a essência mesma de cada subjetividade, seria esse núcleo de disposições que determina as reações particulares de atração ou de repulsão experimentadas diante das pessoas ou das coisas e que, conseqüentemente, nos permitiria não somente antecipar nosso próprio sentir em relação a experiências até então não vivenciadas, mas igualmente prever (até certo ponto) as atitudes de nossos próximos nas situações concretas da vida cotidiana..

No segundo texto, Fontanille e Zilberberg afirma que “...c'est la phorie qui permet de passer des valeurs virtuelles du système aux valeurs existentielles du processus...". É preciso lembrar aqui que a partir dos estudos efetuados nos E ssais sur les Modalites Tensives (1981), Zilberberg propõe que a categoria tímica seja redefinida como categoria fórica.

Nos dois casos, tanto em Landowski, quanto em Fontanille e Zilberberg, é difícil pensar em "reações particulares de atração ou de repulsão" ou em "valores virtuais do sistema e valores existenciais do processo", sem levar em contar os alicerces da categoria tímica estabelecidos por Greimas em "D e la modalisation de l'être".

Há, então, no início da década de noventa, uma nova perspectiva de análise, a qual dá privilégios para essa sensibilização tímica. A relação entre o tímico, o imaginário social e a vida cotidiana passa a ser compreendida sob um outro enfoque a partir do conceito de valência formulado por Greimas e Fontanille em Semiótica das Paixões (1993). Assim, tem início uma trajetória que acaba por instaurar um ponto de vista subjetivo nas pesquisas semióticas, iniciando 
um percurso que vai chegar até as propostas da Gramática Tensiva. 0 conceito de valência é definido e ajuda-nos a compreender como se processa a formação do valor.

Ao propor as valências junto com $\mathrm{G}$ reimas e, mais tarde, ao delimitá-las com maior rigor junto com Zilberberg ( $\mathrm{V}$ alenœ, $\mathrm{V}$ aleur, 1996a e $\mathrm{G}$ rammaire Tensive, 1996b), Fontanille retoma 0 isomorfismo dos planos formulado por Hjelmslev e estabelece o valor como uma função gerada por dois funtivos, duas valências: intensidade e extensividade.

Observando o plano da expressão, e considerando a Fonética e a Fonologia como 0 estudos sobre a expressão, temos os conceitos de amplitude e freqüência, responsáveis, respectivamente, pela intensidade e altura dos sons. Assim, o som tem como base a amplitude e freqüência e a sua configuração será marcada tendo em vista essas características da onda sonora relacionadas aos harmônicos que a compõem e ao meio de ressonância.

Partindo dessas relações fonéticas básicas, Fontanille, desta vez com Zilberberg, examina no plano do conteúdo a construção do conceito de valor em função de componentes fundamentais, agora não mais amplitude e freqüência, mas intensidade e extensividade; isto é, as valências, cuja relação produz como efeito de sentido o valor e têm como suporte para suas relações o eixo paradigmático e o sintagmático. Fontanille e Zilberberg desenvolveram esse trabalho e publicaram em 1998 a obra T ension et Signification, cuja tradução para o português é de 2001. As considerações aqui elaboradas estão baseadas em anotações feitas durante 0 curso Tópicos sobre o Lugar do Tempo na Teoria Semiótica, ministrado pelo Prof. Claude Zilberberg em 1997 na Faculdade de Filosofia, Letras e Ciências Humanas da Universidade de São Paulo, bem como na bibliografia indicada para consulta.

Fontanille e Zilberberg (1996b:15) nos explicam que o termo valência é um termo consagrado na Química há bastante tempo. Tesnière foi quem o empregou primeiramente na Lingǘstica para designar o número de posições actanciais ligadas ao predicado na estrutura de base da frase. A valência caracteriza, ao mesmo tempo, a ligação tensiva e o número de ligações que associa um núcleo a seus periféricos. Os periféricos são definidos pela atração que o núcleo exerce sobre eles e pela potencialidade de atração do núcleo, remetendo ao número de periféricos que o núcleo é susceptível de agrupar sob sua dependência. Há um efeito de coesão produzido pelas relações de dependência entre o núcleo e os periféricos. Um efeito de coesão proveniente de forças de atração - coesão essa que será caracterizada, em Semiótica, pela 
homogenização do corpo sensível que impregna o discurso de um "perfume" tímico-sensível (G reimas e Fontanille, 1993:13).

Do ponto de vista da Lingǘstica, a valência indica a emergência de um protótipo numa categoria semântica; ou seja, uma rede de dependências que une as ocorrências sensíveis que constituem a categoria, estabelecendo uma coesão sensível, a partir da qual se vêem desenhados os limites e, como conseqüência, as oposições constitutivas da categoria. Trata-se de uma sensibilização funcionando como "poder de atração" e este "poder" constituiria uma espécie de embrião das oposições que estruturam o sentido no campo fundamental. Tem-se, então, uma forma sensível de compreender a formação das identidades e diferenças propostas por Saussure.

$O$ conceito de valência aparece no livro Semióticas das Paix ões (1993) como "o valor do valor" e foi incorporado à Semiótica em função de uma constatação na análise dos discursos: 0 valor dos objetos tem tanta intensidade, quantidade, aspecto ou tempo de circulação, quanto conteúdos semânticos e axiológicos que os fazem objetos de valor (Fontanille e Zilberberg, 1996b:15).

De acordo com Fontanille e Zilberberg (1996b:16), a morfologia dos objetos e as modulações dos processos de circulação levam a estabelecer uma correlação entre 0 valor propriamente dito e dimensionar a distinção entre, de uma parte, os investimentos semânticos dirigidos sobre os objetos de valor e, de outra parte, as condições tensivas e figurais que sobredeterminam e controlam esses investimentos semânticos. Isto significa que o conceito de valência e o conceito de valor não são, eles mesmos, suficientes: eles só são determinantes como partes portadoras de uma semiose imanente no seio da qual a valência seria manifestada e 0 valor manifestante.

Nota-se que, nessa introdução do conceito de valência e de valor, Fontanille e Zilberberg assumem a tradição da lingüística desde Saussure, passando por Hjelmslev e Troubetzkoy.

Ao propor esses conceitos, em primeiro lugar, considera-os de acordo com Saussure, assumindo-os como uma grandeza que só existe em virtude de uma solidariedade absoluta - valor e valência mantêm entre si uma íntima união tal qual no signo saussuriano e mostram os mecanismos de construções lógico-sensíveis que sustentam a formação das identidades e diferenças responsáveis pelas configurações semânticas elementares. Esses conceitos são, 
também, definidos como funtivos de uma função - a função semiótica que estabelece uma relação de dependência entre seus funtivos, numa clara referência a Hjelmslev.

Entretanto, os fundamentos semiolingüísticos da G ramática Tensiva não ficam limitados apenas a esses dois apectos. Há, antes de mais nada, a retomada também de Hjelmslev, desta vez junto com Greimas em Semântica Estrutural (1976), assumindo o isomorfismo dos planos e compreendendo o plano do conteúdo correlato aos parâmetros propostos por Troubetzkoy para o plano da expressão. Esse é um dos pontos que merecem mais cuidado nas análises: a presença de Troubetzkoy.

Há, por exemplo, duas afirmações de Troubetzkoy nos Princípios de Fonologia (1976) que podem indicar algumas diretrizes que norteiam também esses trabalhos sobre valor e valência:

Nos casos típicos em que se atribuem valor monofonemático aos grupos de consoantes, se notará facilmente que se trata sempre da dissociação progressiva com um complexo articulatório. (1976:49).

As regras a respeito do valor monofonemático ou polifonemático de um som se baseiam na estrutura do sistema correspondente e no papel especial que dentro desse sistema desempenha o som considerado. (Polianov, apud Trubetzkoy, 1976:56).

Troubetzkoy, quando explica o valor monofonemático e 0 valor polifonemático, diz haver sempre um complexo articulatório na composição do fonema, a partir do qual os valores dos fonemas devem ser dimensionados; portanto essa dimensão é aqui também fruto da relação dos componentes fonológicos. A citação de Polianov reforça essa idéia, pois ressalta a necessidade de considerar um sistema que vai, a partir das relações ali estabelecidas, indicar as proporções e dimensões dos processos fonológicos.

Assim, quando Fontanille e Zilberberg falam em valor e sua correlação com as condições tensivas e figurais sobredeterminando os investimentos semânticos, há também a preocupação de situar um complexo fundamental, primeiro, a partir do qual os valores devem ser dimensionados. 
Esta presença da tradição semiolingüística é cada vez mais clara no desenvolvimento das análises sobre valência e valor. 0 trabalho vai sendo estruturado a partir dos eixos paradigmático e sintagmático, o que significa mais uma referência ao C urso de L ingǘstica $\mathrm{G}$ eral.

É por meio da abordagem do eixo paradigmático que os autores começam a delimitar de forma mais precisa o conceito de valência. Procuraremos aqui indicar apenas os pontos básicos dessa proposta para que se possa perceber a trajetória do valor na Semiótica.

$\mathrm{Na}$ análise do eixo paradigmático, a valência contribui para a significação do próprio paradigma e estabelece a relação paradigmática como ponto de partida para a organização de uma categoria, isto é, aponta a categoria como uma conseqüência, uma resultante da relação paradigmática.

Assim, a compreensão paradigmática da valência, de acordo com Fontanille e Zilberberg(1996b:15-25), tem por objetivo precisar o elo entre a definição e o paradigma; ou melhor, munida de sua definição, uma grandeza semiótica intrinsecamente complexa pode se inserir num inventário regular de oposições. Observando as variações de uma definição lexical no dicionário, percebe-se que uma definição instala uma divisão, uma diferença, uma desigualdade e um conflito entre duas direções, cada uma dessas direções, produzindo um efeito de perspectiva. Cada definição possui um efeito de perspectiva de acordo com a posição e o interesse do observador. Por um lado, há uma escolha classemática; por outro, uma variação (um delta, um gradiente) tímica, conferindo um traço tônico (forte) ou átono (fraco).

A correlação sobre a qual repousa a definição associa o classema a um efeito tímico, assim, qualquer que seja a definição, isto é, qualquer que seja a escolha classemática, ou o efeito tímico (tônico ou átono), qualquer escolha que for feita revela um sistema de valências. Dessa forma, a valência poderia ser caracterizada aqui como a correlação entre dois gradientes: de profundidade classemática e de tonicidade tímica. Valência é, portanto, o grau de variação, 0 delta de variação entre o classemático - uma categorização - e o tímico - o sentir do sujeito.

Neste momento, Fontanille e Zilberberg frisam as bases hjelmslevianas (conseqüentemente, retomando Troubetzkoy) ao considerarem o grau de variação tímica como um gradiente de intensidade - as proporções fracas ou fortes (tônicas ou átonas) das atrações e repulsões do ser no mundo - e o grau de variação classemática - o recorte, a intersemioticidade 
operada entre as duas macrossemióticas, língua natural e mundo natural - como gradiente de extensividade. Assim, intensidade e extensividade são funtivos de uma função, o que mostra a conformidade com o modelo proposto por Hjelmslev.

A intensidade é estabelecida como a energia que comporta a percepção; já a extensividade se caracteriza como morfologias quantitativas do mundo sensível que guiam ou contrariam o fluxo de atenção do sujeito . No espaço tensivo, esses gradientes são colocados em perspectiva pela visão e pela compreensão do sujeito perceptivo. Essa orientação dos gradientes com relação a um centro dêitico e com relação a um observador os converte em profundidades semânticas. Trata-se, então, de profundidades articulando um espaço mental mais ou menos abstrato, um espaço epistemológico de categorização, mais isomórfico do que aquele da percepção, e diretamente derivado dele: a profundidade semântica obedece a mesma definição que a profundidade figurativa; há somente uma mudança no grau de abstração.

Antes de prosseguir as análises sobre 0 valor e as valências, é preciso destacar alguns pontos. Ao definir as valências a partir de suas relações paradigmáticas, isto é, como ponto de partida para a formação de um paradigma, de uma categoria, e determinar como operações sintáticas a seleção classemática (diferenças com relação a outras categorias) e variação tímica (forte/ tônico, átono/ fraco), observamos que nesta definição foram respeitadas as mesmas regras de operação propostas por Saussure, passando por Hjelmslev e Greimas. Entretanto, o que se altera é o privilégio dado ao sensível, ao tímico, às forças de atração e repulsão que dirigem a percepção. É como se a Gramática Tensiva assumisse a contribuição, a herança deixada por Greimas em Da Imperfeicão e Semiótica das Paixões e anexasse essa contribuição ao seio dos conceitos semiolingǘsticos. O caminho da apreensão do mundo pelo sujeito sensível e a apropriação gramatical pelo objeto das funções do sujeito são retomados e aprofundados; e com isto é recuperado um diálogo com a fenomenologia que o próprio Greimas havia deixado um pouco de lado desde Semântica E strutural (1976): “...nos propomos a considerar a percepção como o lugar não lingüístico onde se situa a apreensão da significação" (G reimas, 1976:15).

Chamamos atenção aqui para a aparente subjetivação do conceito de valor, relacionada à percepção do sujeito sensível como determinante dos gradientes que irão compor os funtivos da relação que estabelece 0 valor. É a posição do sujeito investindo no objeto a partir de sua percepção sensível. Esta é uma concepção dos fundamentos do valor próxima daquela que mencionamos em nossa análise sobre as relações entre sujeito e objeto no palco das trocas e isto 
traz algumas consequêencias que podem ser elucidadas a partir da compreensão da categoria tímica.

É necessário, então, ressaltar que essa subjetivação do conceito de valor, fundamentando a formação do valor na categoria tímica e, conseqüentemente, na percepção do sujeito sensível, deve ser analisada tendo em vista aquilo que funda a subjetividade; ou seja, qual a dimensão desse sistema de atrações e repulsões determinado pela categoria tímica. Conseqüentemente, não se deve deixar de lado a questão da subjetividade ser uma subjetividade fundada no indivíduo ou na pessoa. Tendo em vista a sociedade construída sobre o mercado, sobre o palco das trocas, é importante analisar as identidades e diferenças elementares que guiam as atrações e repulsões do sujeito sensível. Essas atrações e repulsões são produzidas pela consciência racional, psicológica e ontológica do eu, pelo indivíduo, ou são produzidas pelo papel ético e jurídico, pela racionalidade instrumental, pelo condicionamento cognitivo, pela máscara, pela pessoa?

Este tipo de reflexão deve levar em conta as afirmações de Greimas sobre a forma pela qual o objeto se apropria gramaticalmente das funções do sujeito e deve levar em conta também o papel do mercado como um grande destinador nos textos apresentados pela vida cotidiana. Os objetos e a formação do seu valor partem do ponto de vista do sujeito sensível e perceptivo, mas essa sensibilidade acaba por ser apropriada pelo objeto, tornando ele mesmo fonte de atração e repulsão e, por meio do palco das trocas, há a produção de um campo sensibilizado que dirige 0 sistema de atrações e repulsões próprio do sujeito e o faz constituir-se mais pela máscara do que pelo indivíduo. Isto nos ajuda a pensar de forma um pouco mais clara nas palavras de Greimas. Os objetos sensíveis e o campo de equivalências potencializado por essas sensibilizações fazem com que "nossas almas e nossos corpos estejam culturalizados e relativizados" no seio da vida social.

A pessoa e o indivíduo, as dimensões ontológicas e a máscara levam a considerar o ser e 0 pareerer em um movimento que vai aprofundar e tornar mais intrínseca a relação entre a imanência e a aparência. $O$ sujeito erguido pelo domínio de um outro grande sujeito ganha a máscara desde sua gênese: são as almas e os corpos relativizados. 0 parecer invade o domínio do ser e o que era até então considerado como oposição pontual ganha as proporções de uma gradação sobre um dado eixo semântico; ou melhor, relacionando com o que nos expõe Greimas no artigo "Le savoir et le croire: un seul univers cognitif" (D u Sens II, 1983:116) há uma "estrutura elástica" que no momento de tensão produz uma polarização, uma categoria, mas quando relaxada chega 
a confundir os dois termos. $\mathrm{O}$ ser e o pareer ganham essa elasticidade que $\mathrm{G}$ reimas atribui ao saber e ao crer graças ao campo sensibilizado relativizado e culturalizado sobre o qual se ergue 0 sistema de atrações e repulsões próprio do sujeito.

As propostas de Fontanille e Zilberberg sobre as valências (1996b, p.25-9) prosseguem, traçando a dimensão da percepção do sujeito sensível e nos auxiliando a compreender melhor as relações entre sujeito e objeto na formação do valor. Assim, o próprio corpo do "sujet sentant" encontra uma definição como o lugar no qual se fazem e se revelam, ao mesmo tempo, as correlações entre as valências perceptíveis (intensidade e extensividade).

O conceito de valor aparece aqui como sustentado pela sensibilização tímico-tensiva do nível fundamental - por isso é importante analisar as dimensões dessa sensibilização tímica, contextualizando-a nas sociedades de mercado. É preciso compreender a forma pela qual são associadas as duas valências, os dois gradientes orientados e correlacionados - as duas valência, extensividade e intensidade, que são os funtivos da função-valor -; e é preciso também, seguindo mais uma vez as propostas estabelecidas no Curso de Lingǘstica $G$ eral, caracterizar o modo de combinação dessas valências, ou seja, caracterizar a definição sintagmática da valência. Essa definição sintagmática é guiada pela tensão entre conjunção e disjunção, o que obedece as mesmas balizas traçadas por Greimas em "Un problème de semiotique narrative: les objets de valeur" (D u Sens II, 1983:19-48).

No caso da conjunção, a relação que se estabelece é a relação "e ... e"; ; isto é, as valências variam no mesmo sentido: 0 menos atrai sempre 0 menos e 0 mais atrai sempre 0 mais. Trata-se, então, de uma correlação conversa. No outro caso, a disjunção, as valências variam na razão inversa uma ou a outra; assim, a textualidade produz dois tipos de enunciados: mais atrai menos e menos atrai mais, sendo esta a correlação inversa. (Fontanille e Zilberberg, 1996b:26).

A coexistência desses tipos de regimes funcionais delimita espaços de acolhimento plausíveis para os dois grandes princípios postos em jogo pela Antropologia: 0 princípio da exclusão - tendo por operador a disjunção - e o princípio da participação - tendo por operador a conjunção. Os micro-universos discursivos parecem conjugar esses dois princípios e, dessa forma, compor formas de vida. É preciso frisar, então, que a valência comporta a substância: ela só alcança a forma se colocada em jogo pelos dois grandes princípios - exclusão e participação. 
Esses dois princípios dão a noção do limite das imagens opostas: pelo princípio de participação, em correlação conversa, cada gradiente (delta de variação) parece poder recuar indefinidamente o limite do outro, engendrando assim, sempre mais e mais, e sempre menos e menos - o mais sempre atraindo o mais e o menos sempre atraindo o menos.

Quanto ao princípio de exclusão, em correlação inversa, o limite não é mais situado nos extremos, mas no equilíbrio das valências concorrentes. A diferença entre categorias de fronteiras frágeis e categorias de fronteiras claras poderia, então, ser estabelecida graças à distinção entre correlação conversa (regime participativo) e correlação inversa (regime exclusivo).

$\mathrm{Na}$ análise sintagmática, os dois regimes de valência - 0 princípio de exclusão e 0 princípio de participação - se realizam localizadamente na cadeia, convocando os valores dois a dois, e cada um apresenta suas próprias particularidades sintagmáticas. 0 regime de exclusão tem por operador a seleção, e resulta, se o processo atinge seus termos, na confrontação do exclusivo e do excluído. Trata-se da opção entre a identidade e a diferença.

O regime de participação que tem por operador a combinação (mistura/ mélange) acarreta a confrontação entre o igual e o diferente. No caso da igualdade, as grandezas são intercambiáveis, ao passo que, no caso da desigualdade, essas grandezas são opostas como superiores ou inferiores.

Levando em conta os dois componentes - sintagmático e paradigmático -, temos que, por um lado, o sintagma, o eixo de combinações, passa a operar tendo como base a relação de junção - conjunção e disjunção. Essa relação gera dois tipos de correlação: correlação conversa e correlação inversa, as quais, por sua vez, engendram dois princípios que vão operar as combinações, as articulações sintagmáticas: princípio de participação e o de exclusão. Por outro lado, no paradigma, a valência requer dois gradientes, dois deltas de variação, dois componentes que atuam como funtivos da função-valor: extensividade, definida a partir do classemático, e intensividade, definida a partir do tímico.

Cabe aqui uma observação para frisar, mais uma vez, como esse tipo de análise elaborada por Fontanille e Zilberberg se enquadra no desenvolvimento das pesquisas semiolingüísticas. O s princípios de disjunção e conjunção, bem como as correlações inversas e convexas, não são propostas isoladas. De acordo com nossas análises anteriores, o texto de Greimas “Un problème 
de semiotique narrative: les objets de valeur" (1983:19-48) compõe uma minuciosa descrição do valor tendo em vista a sintaxe operadora nas transformações narrativas.

Aspectos como valores objetivos e valores subjetivos, junção sintagmática e junção paradigmática, transferência de objetos e comunicação entre sujeitos, troca virtual e troca realizada mostram a origem de todas as articulações retomadas pela $\mathrm{G}$ ramática Tensiva. Mostram que não são apenas retomadas a estrutura paradigmática e a estrutura sintagmática, mas os próprios princípios de operacionalização do modelo semiótico, cujas bases as transformações narrativas já havia estabelecido. Assim, o que parece estar sendo feito é uma projeção das articulações narrativas na composição dos valores, agora considerada desde o nível fundamental. Há uma projeção, é como se o eixo narrativo refletisse suas articulações no campo fundamental, como se o eixo narrativo invadisse, com sua lógica juntiva, o campo fundamental, operando uma sintaxe de construção das formas entre identidades e diferenças, cujo delta de variação entre essas identidades e diferenças produzisse a valência, uma forma sensível de apreender 0 valor proposto por Saussure no C urso de L ingǘstica $G$ eral. É como se na própria composição do campo de equivalências semânticas elementares houvesse uma sobredeterminação - tímico e classemática, por um lado, e juntiva, por outro - reafirmando os proto-valores lingüísticos que ali estão se constituindo.

D essa forma, a rearticulação das valências em valores no espaço narrativo supõe que as dependências/independências sejam convertidas em identidades e diferenças (contrariedade, contradição, complementaridade), a partir das rupturas observadas na rede de dependências, de sorte que o limiar ou o limite projetado sobre as valências torna-se fronteira de uma categoria estabilizada ou discretizada. Da mesma forma, o sujeito sensível, tornando-se sujeito sêmionarrativo, vê seu universo repartir-se axiologicamente graças à polarização euforia/ disforia, já que, no espaço tensivo, a foria não polarizada caracterizaria as reações de seu próprio corpo às tensões, às quais ele estaria ligado. Assim, surge o valor no sentido semiótico: 0 valor como diferença que organiza cognitivamente o mundo observado, e o valor como jogo axiológico que polariza a própria visão de mundo. Confirma-se, desse modo, uma definição de valor que segue o percurso de Saussure a Greimas; por sublinhar a diferença, com relação ao primeiro; e por consolidar o papel do sistema de atrações e repulsões próprio da categoria tímica com relação ao segundo. 
Retomando a questão das valências, a semiótica da seleção é, de alguma forma, abrandada pela solução de continuidade estabelecida entre 0 exclusivo e o excluído. Na semiótica da combinação, o tempo de circulação é mais vivo na cultura em que a valência é mais difusa do que naquela em que a valência tende a se concentrar sobre um número restrito de grandezas. Assim, efetuando uma análise do domínio do mercado, sob o ponto de vista das valências, podese dizer que 0 valor de troca de uma mercadoria como a moeda, depende da velocidade (inflação) ou da lentidão (deflação) com a qual as mercadorias são trocadas. Isto traz conseqüências diretas para a compreensão da circulação de bens nas sociedades de mercado.

As relações sintáticas no campo elementar da significação impõem que se opere, paralelamente, com o princípio da exclusão e com o princípio da participação. É preciso a combinação, a participação, a confrontação contínua entre 0 igual e 0 diferente, 0 estabelecimento constante de posições de igualdade e superioridade. As valências, o tímico e 0 classemático precisam estar difusos nesta sintaxe de conjunção; 0 tempo é mais vivo e permite a velocidade acelerada da circulação dos objetos. O desejo do sujeito perceptivo e as determinações classemáticas estão difusas; a combinação e as conjunções são mais rápidas. É a velocidade dos tempos do mercado globalizado. Trata-se da perspectiva macro, do macrotexto configurado pela sociedade global.

No entanto, paralelamente a este movimento, atuando como uma força de reação à pontecialidade de conjunções, opera-se uma sintaxe de exclusão, descontínua, que restringe 0 movimento de conjunções relacionado ao sujeito; ou melhor, à constituição do sujeito. Este proto-sujeito que se ergue no interior de uma velocidade de conjunções acaba por refratar esse movimento acelerado de conjunções, provocando disjunções, fragmentações, descontinuidades em sua própria constituição. Constata-se, então, mais uma vez, a tensão entre 0 valor e as valências. As valências pressupõem a ambivalência do objeto e a instabilidade do sujeito: é no interior dessa tensão entre ambivalência e instabilidade que se constitui o valor.

Dessa forma, a proposta feita pela Gramática Tensiva situa o sujeito como um sujeito sensibilizado desde as pré-condições da significação estabelecidas no campo fundamental. Há, desde o campo mais profundo e abstrato, um proto-sujeito sensibilizado que vai se concretizando, por um lado, como o sujeito do sentir, tenso e afetado pela intensidade; e, por outro lado, um sujeito do perceber, aquele que apreende a projeção de um mundo categorizado, 
preocupado com o número e a quantidade e, na qualidade de possível sujeito do querer (sujeito volitivo), tendo que ajustar as correlações inevitáveis entre as valências.

Q uando, nessa perspectiva, é levada em conta também a distinção entre sujeito e objeto, notadamente no ato perceptivo, é possível dizer que as valências de intensidade e de tempo caracterizariam essencialmente 0 devir sensível do sujeito; e as valências de extensividade caracterizariam o devir do objeto. Assim, pode-se chegar às valências subjetais, isto é, subjetivas, relativas ao sujeito; e às valências objetais, objetivas, relativas ao objeto .

As valências subjetivas determinam as condições de acesso ao valor pelo sujeito. Dessa maneira, o valor da junção, de natureza essencialmente "rítmica", poderia ser identificado graças ao tempo e à aspectualização da apreensão ou da troca. É assim que "o valor para o sujeito" se desenha segundo o que ele é capaz ou não é capaz de modular na rapidez do processo que resulta da junção.

As valências objetivas determinam a morfologia das figuras-objetos, o que as torna apropriadas para receber um investimento axiológico. Desse modo, as formas particulares da dependência e da independência que unem as partes do mundo sensível, preparando e determinando o tipo de valor, poderiam ser investidas e os limites do campo disponível podem ser compreendidos sobre o plano estético. É assim que a fonte da perfeição não assinala somente uma certa concepção do belo, mas pode também ser compreendida como a manifestação discursiva de uma valência que estabeleceria, por exemplo, a autonomia do objeto sensível ausência de dependência exterior perceptível - ou o fechamento da compreensão perceptiva, 0 estatuto de uma condição prévia ao investimento axiológico.

Essas referências ao objeto como um objeto sensível, ou seja, a sensibilidade prédeterminada pelo componente tímico e moldada por parâmetros sócio-culturais está também em Semiótica das Paixões (1993:21), quando atribui o componente passional não exclusivamente ao sujeito, mas ao discurso inteiro. Constata-se aí também uma sensibilização do objeto e a conseqüente descaracterização do objeto como alvo exterior ao sujeito, impregnando-o de uma sensibilidade fundada a partir do ponto de vista do sujeito, do tímico, do modo de atração e repulsão do ser no mundo. 
Tendo em vista essa análise da formação do valor a partir das valências elaboradas no texto Fontanille e Zilberberg, é possível ampliar um pouco essa perspectiva e pensar nas propostas da Gramática Tensiva de forma um pouco mais geral.

Primeiramente, ainda enfocando o conceito de valor, constata-se aqui a nítida presença do caminho aberto por Greimas em D a Imperfeição, pois há a introdução do sensível no valor através da intensidade. Assim, tendo como ponto de partida uma das valências, a dimensão afetiva passa a ser constitutiva do valor.

No entanto, essa dimensão afetiva, essa subjetividade, é postulada na Teoria Semiótica de maneira extremamente formal. Trata-se de inserir os afetos no seio da perspectiva semiótica de modo a não deixar que a instabilidade e ambivalência da persepção sensível possam comprometer as bases do modelo. Diante de tal tarefa, a Gramática Tensiva parece ter recorrido àquilo que mais a torna sólida, em termos epistemológicos, a base hipotético-dedutiva da perspectiva semiótica: os fundamentos teóricos propostos por Hjelmeslev em seus Prolegômenos (1975).

Não é apenas a presença das bases hipotéticos-dedutivas que conduzem a Gramática Tensiva nessa afirmação dos fundamentos epistemológicos. É possível também notar a formalização lógico-dedutiva por meio de gráficos e conceitos matemáticos estabelecidos na construção teórica das valências (Fontalinelle e Zilberberg, 1996b) e assim observamos a presença matemática auxiliando a elaboração teórica do conceito de valor. Trata-se então de verificar, no seio da Gramática Tensiva e correlativamente no seio da Semiótica, essa busca pela constatação positiva. Essa obsessão pela positividade lógica e matemática como forma de obter uma sanção favorável no mundo das ciências; como se, dentro da própria teoria da linguagem, as palavras não fossem suficientes para alcançar a precisão que fizesse com que a Semiótica ocupasse seu devido lugar no quadro das Ciências Sociais.

Partindo dos fundamentos de Saussure e Hjelmslev, a Gramática Tensiva passa a repensar as transformações estabelecidas na sintaxe narrativa, projetando-as no campo elementar. A utilização do conceito de junção, por exemplo, ilustra bem esse movimento. A junção é um conceito formulado já nos Prolegômenos de Hjelmslev e retomado exaustivamente por G reimas na análise da narrativa efetuada em D u Sens II. Assim, levando em conta as propostas de Fontanille e Zilberberg, o que nos parece é que a narrativa permanece como uma linha de descontinuidade direcionando os rumos das transformações, orientando as mudanças de estado; 
ou seja, um eixo de sentido entre as forças potencializadas do campo tímico-tensivo elementar e do campo discursivo aspectualizado.

É importante aqui chamar a atenção, mais uma vez, para a substituição da noção de nível pela noção de campo. A conceituação envolvendo o campo remete a uma idéia mais abrangente, na qual não há uma linearidade pré-estabelecida, mas sim a ação de um fluxo magnetizando várias forças de atração e repulsão. 0 valor passa, então, a ser dimensionado nesse contexto; não mais como algo pontual, fruto de uma relação polarizada entre sujeito e objeto, mas como um campo sensibilizado de atuação.

Ressalta-se aqui, também, a abertura que Fontanille e Zilberberg efetuam e que nos interessa de perto. Apesar de essa análise instalar um "observador sensível", dando assim privilégio ao ponto de vista do sujeito, essa perspectiva não descarta a preocupação com a dimensão sócio-cultural, remetendo, por isso mesmo, a um outro tipo de reflexão: de que forma a dimensão macrossocial é instaurada quando o enfoque é dado pelo observador, pelo sujeito. Há, assim, necessidade de entender uma dimensão social concebida de uma forma sensibilizada, sobredeterminada, o que a diferencia daquela explorada nos anos oitenta.

Uma outra linha de pesquisas desenvolvida a partir da herança deixada por G reimas está presente nos trabalhos de Landowski, Fiorin e outros pesquisadores. Trabalhos como La Société Réfléchie de Eric Landowski de 1989 mostram que, desde as últimas décadas do século XX, já havia uma preocupação com novas propostas em Semiótica. Escolhemos aqui a obra, 0 G osto da G ente, G osto das Coisas (1997) de organizada por Eric Landowski e José Luiz Fiorin, cuja proposta é formular uma Gramática do Sensível, por indicar uma abordagem do sensível em Semiótica diversa daquela apresentada pela Gramática Tensiva. É preciso frisar que são perspectivas diversas, mas não necessariamente excludentes.

O artigo de Eric Landowski "Gosto se discute" (1997:97-160) publicado na obra 0 G osto da $\mathrm{G}$ ente, $\mathrm{G}$ osto das $\mathrm{C}$ oisas mostra em seu último parágrafo essa proposta de uma gramática que dê conta de compreender os movimentos narrativos e discursivos sobredeterminados por uma aspectualização que imprime um ponto de vista sensível sobre o discurso:

Ninguém inventa substâncias novas (no sentido hjelmsleviano da palavra), mas alguns sabem articulá-las de modo inesperado, produzindo, às vezes, efeitos de sentidos iluminadores, e gostos bons. Mais modestamente, a tarefa atual da semiótica - a "do gosto", em si - é tentar dar conta desses acidentes felizes e, para tanto, construir a gramática do sensível que 0 
permitiria. Tal é, em particular, o objetivo da parte que se segue no presente volume." (Landowski, 1997:160)

É conveniente, então, compreender porque foram traçadas duas linhas a partir, principalmente, da publicação de D a Imperfeição (2002), cujo original francês data de 1987. Por um lado, a Gramática Tensiva preocupa-se em estabelecer um arcabouço teórico que possa dar conta dessa carga sensível que impregna o sentido e que foi reassumida pela Semiótica depois de ter sido deixada provisoriamente de lado desde Semântica Estrutural (1976). Por outro lado, a Gramática do Sensível está interessada diretamente em compreender os efeitos de sentido que essa sensibilização pode gerar nos diversos discursos fornecidos pelas interações sociais, pelas práticas cotidianas, pelas construções da estética.

Da mesma forma que a Gramática Tensiva, a proposta da Gramática do Sensível também opera uma aspectualização do percurso gerativo a partir das sobredeterminações tímicas do campo fundamental. É como se o ponto de vista do sujeito sensível aspectualizasse toda a construção do sentido; como se o sentir do sujeito se instalasse no próprio percurso sobredeterminando-o e projetando o "perfume sensível" no efeitos de sentido produzidos no discurso.

Há, na perspectiva da Gramática do Sensível, a proposta de "uma teoria implícita do gosto" (Fiorin e Landowski, 1997:103), a qual tem em vista a fundamentação da norma a partir da qual o gosto é construído; e é nessa teoria que se posiciona o papel do sujeito sensibilizado e sua interferência nas normas condutoras da formação do gosto. 0 papel do sujeito nessa proposta pode ser melhor compreendido observando as palavras de Landowski (Fiorin e Landowski, 1997:103-104) sobre os objetivos das pesquisas: “Limita-se à compreensão das várias formas de gosto 'da gente' (e não 'das coisas'), tais como elas se manifestam nas práticas sociais, em relação com a construção e o devir dos sujeitos, ou seja, da figura actancial assim denominada na teoria geral da significação." 
Entretanto, o que parece distinguir os dois enfoques é uma hierarquia de interesses e a maneira como o sujeito é dimensionado. Enquanto a Gramática Tensiva está voltada para a tarefa de reformular as bases teóricas do modelo, a fim de que a preocupação com o sensível ganhe um sólido alicerce epistemológico, a Gramática do Sensível tem em vista a análise discursiva, objetivando, também, questionar as bases sócio-culturais do sentir, pois busca uma sintaxe das normas que conduzem o gosto. Assim, o sujeito sensível é redimensionado mediante uma sintaxe subjacente que direciona sua sensibilização.

Mas o que nos interessa de perto neste trabalho é exatamente a questão do valor; e neste ponto é preciso sublinhar que, embora por caminhos distintos, tanto a Gramática do Sensível, quanto a Gramática Tensiva, assumem como núcleo das indagações exatamente essa questão do valor.

A Gramática Tensiva constrói suas análises partindo do papel desempenhado pela valências na formação do valor; e a Gramática do Sensível, ao analisar precisamente o gosto, não deixa de analisar a relação entre sujeito e objeto, pois, tanto esse objeto quanto esse sujeito só adquirem existência semiótica a partir do momento em que se estabelece entre eles uma relação de transitividade, uma relação investida de desejo, um gosto, passando, assim, o objeto a merecer o gosto do sujeito, a ser objeto de valor.

Dessa forma, o que se altera é a forma de conceber a relação entre sujeito e objeto. Esta relação é agora reavaliada à luz das sobredeterminações tímico-tensivas, o que, conseqüentemente, leva também a uma reavaliação do percurso gerativo, tal qual nos havia antecipado G reimas em seu "D e la modalisation de l'être" (D u Sens II, 1983:93-102).

A preocupação nos estudos da Gramática do Sensível passa a ser um valor sensibilizado, por isso mesmo reinvestido semanticamente: é um gosto. No entanto, chama a atenção aqui 0 enfoque macrossocial que é dado a essas análises. Trata-se de buscar uma sintaxe das normas sociais, um fundamento nos comportamentos individuais - nos valores, nos gostos - que permita distinguir de que forma há um arranjo particular do sistema de atrações e repulsões que possibilita formalizar certos gostos, os quais definem e especificam o sujeito precisamente como sujeito individual. É, em última instância, a preocupação com a fundação do sujeito e a constituição de sua identidade, observadas sob a óptica da construção dos efeitos de sentido. 
O gosto passa ser compreendido como identidade, num movimento de afirmação do C urso de L inguística $G$ eral. A relação sensibilizada entre sujeito e objeto produz, então, um valor sensibilizado, um gosto, e esse valor vai sustentar aquilo que é diferença. Há uma identidade, uma norma social de gosto, entretanto, particularizada pela aspectualização do sujeito sensível que impõe um gosto, uma diferença.

Ao mesmo tempo, a Gramática do Sensível propõe, além da continuidade provocada pela presença do sujeito sensível, as descontinuidades decorrentes das transformações narrativas. As pesquisas sobre 0 gosto buscam na narratividade a explicação daquilo que pode parecer contraditório na superfície, pois reconhecem a distinção entre níveis de abstração que podem assegurar uma coerência mais profunda, quando se observam as relações entre sujeito e objeto sem a cobertura da figuratividade de superfície.

Neste aspecto referente à narratividade, cabe destacar que a presença do sujeito sensível impregna as articulações da sintaxe narrativa com uma carga tímico-tensiva, o que obriga a uma nova avaliação das relações entre sujeito e objeto. Isto pode ser constatado quando se observa a análise das relações intersubjetivas e verifica-se a distinção entre gostos objetais e gostos subjetais Na realidade, mais uma vez estamos detectando a presença de Du Sens II (1983), mais precisamente do artigo "Les objets de valeur". Entretanto a análise de Greimas - valeurs objectives e valeurs subjectives (p.24) - toma agora uma forma sensibilizada, aspectualizada pelo ponto de vista do sujeito sensível, e assim passa a dimensionar o próprio sujeito como um eu sensível que, a partir das transformações narrativas, vai tecendo os contornos das representações desse eu na vida cotidiana (G offman,1985).

Confirma-se, assim, a proposta da Gramática do Sensível, pois há uma análise das consequiências da sobredeterminação tímica e tensiva por meio das relações morfossintáticas subjacentes aos efeitos de sentido produzidos pelo sujeito sensibilizado.

\section{O bjeto sensível}

Diante da Gramática Tensiva e da G ramática do Sensível, observamos, nos dois casos, a proposta de uma forma sensibilizada, aspectualizada, de compreensão das relações sintáticosemânticas envolvidas na construção do sentido e, conseqüentemente, na construção do conceito semiolingǘstico de valor. Nota-se que houve uma aparente subjetivação desse conceito. Há, no quadro geral das Ciências Sociais, uma trajetória que vai desde a objetividade do valor terra 
proposto por Quesnay na Economia até a noção de valor sensibilizado pela presença do sujeito; 0 valor da imperfeição, o valor da utilidade. Esta sensibilização indica o caráter que, à primeira vista, pode ser considerado subjetivo e está presente tanto na concepção semiótica formulada a partir das valências, quanto no conceito de valor utilidade assumido pela Economia.

Trata-se de um percurso que determina um falso esvaziamento do objeto pela invasão da subjetividade. Entretanto, essa invasão é tão intensa que chega a conferir-lhe uma sensibilização própria e, desse modo, confere-lhe o estatuto de objeto sensibilizado.

O texto de Greimas, Da Imperfeicão (2002) dimensiona com clareza esse processo, mostrando a construção de um objeto impregnado de paixão, impregnado de uma modalização que, originalmente, é concebida como modalização do ser, do sujeito de estado. Embora Greimas tome como ponto de partida a experiência estética, essa análise pode ser ampliada e aplicada à concepção que reconhece uma sobredeterminação tímica - sensivel - na formação do valor; pois cabe frisar que o valor é uma função, uma relação entre sujeito e objeto. Greimas aponta a transformação do objeto em objeto de valor sincrético, dotado de memória coletiva e individual, portador de uma significação de múltiplas faces que elaboram redes de complexidade com outros objetos. Trata-se do reconhecimento de um fetichismo irreversível, agora não apenas como um reflexo das relações sociais cristalizadas como características objetivas dos produtos do próprio trabalho, mas como um reflexo sensibilizado dessas relações sociais.

Ao mesmo tempo, é preciso destacar por que fizemos referência a uma aparente subjetivação do valor, a um falso esvaziamento do objeto. Trata-se da necessidade de questionar de que forma essa subjetividade é construída e em que medida a subjetividade revela as marcas da individualidade, ou se o que é na aparência indivíduo é na imanência pessoa. D essa forma, a reflexão sobre o valor deve considerar a distinção entre níveis - o pareeer, por definição manifesto, e 0 ser subjacente, não diretamente perceptível - que gera a existência de uma relação hierárquica entre programas distintos; e, também, a presença do sujeito semiótico, aquele que se insere num percurso de construção social da significação.

O sujeito semiótico é aquele que garante sua existência por comportar uma série de papéis nas interações sociais. Trata-se, portanto, de um sujeito já anteriormente subjetivado, já anteriormente fundado pela dinâmica social, pelas rotas do cotidiano. Assim, é esse sujeito que substitui seus desejos, estes sim, sustentados pelas profundezas de sua individualidade, por necessidades geradas pela vida em sociedade, por gostos provenientes das relações intersubjetivas. 
Verifica-se, então, que, paralelamente a um esvaziamento do sujeito-indivíduo, há um fortalecimento do sujeito-pessoa, de forma que é mantida uma outra espécie de subjetividade uma subjetividade que carrega, por um lado, as necessidades sociais e, por outro, a dissolução dos desejos individuais. Entretanto, esse sujeito, marcado por essa nova subjetividade, é anteriormente um objeto em relação a um macrosujeito social; este sim, gerador das necessidades que alicerçam não só o ser, mas o crer e o fazer do sujeito semiótico. Trata-se, então, não apenas de uma relação entre destinador-manipulador e destinatário-sujeito, mas, de uma relação que vai além disso: os sujeitos tornam-se, eles mesmos, objetos direcionados por um sujeito maior que impõe o crer, o querer e o fazer, moldando-os e objetivando-os; definindo as relações de valor.

É nesses termos que pode ser redimensionada a proposta de Greimas e Fontanille (1993:89) de analisar a Teoria do Valor sob a óptica da Semiótica das Paixões, apontando para 0 aspecto de que, a partir da revolução individualista do século XVIII, "a economia política assume o lugar da teoria das paixões e a teoria das necessidades supera a dos desejos."

Essa questão referente à substituição de uma teoria das paixões por uma teoria das necessidades auxilia-nos a compreender os problemas da subjetividade nas sociedades de mercado. Toda paixão gera um ato avesso, invertido. Um ato ao contrário, um ato egoísta, particular. A paixão tem a nostalgia de um ato intransitivo, mas que vai se construindo, inversamente, por meio de sua transitividade. Sua gênese intransitiva é forçada à incompletude pela necessidade do objeto do desejo, porém sua presença anula a presença do objeto. A paixão não doa, não cede, a paixão possui. É ato de posse, é briga por limites. Faz-nos sentir incompletos. A insatisfação de nos sentirmos imperfeitos, empurra-nos à procura de nos sentir mais aliviados. Procuramos aquilo que nos completa, aquilo por que estamos apaixonados; por isso saímos correndo em desespero atrás do objeto de nossa paixão. Não nos damos conta da intransitividade da paixão, da nostalgia angustiante da estese. 0 desejo do sujeito apaixonado rompe a intransitividade do ser apaixonado. Nasce o objeto do desejo, potencializado, sensibilizado, extenso e tenso; aquele que nos reflete a identidade e a diferença. 0 sujeito apaixonado sai a buscá-lo para aliviar a sensação incômoda do incompleto. Saímos a procura do que nos tem valor; daquilo que vale para nos sentirmos menos inacabados.

O mundo mercantil traçou outros caminhos para a subjetividade: as paixões foram substituídas por necessidades. 0 mercado, o verdadeiro e primeiro sujeito, fez com que desistíssemos da procura do outro e impinge-nos a procura das coisas. Nas coisas, a ilusão da 
posse é mais convincente. Há mais segurança em sentir em nossas mãos o peso de um objeto inanimado, disponível no mercado, mesmo que se trate de um objeto sensível e patemizado. 0 peso do indivíduo é insuportável, de uma intensividade e uma extensividade que jamais caberia nas mãos; insustentável.

A grande contribuição do mundo mercantil, do mundo do capital é desenvolver-nos a ilusão. A ilusão de posse. Tornar ilusoriamente viável os objetos que nos completam. D evolvenos aquilo que fomos ameaçados de perder com o Renascimento. Este tira-nos o alívio da mediação divina, deixando-nos sem a conjunção com a espiritualidade que nos completava.

No lugar do mundo teocêntrico medieval, a modernidade, após um período de tentativas de dessacralização, faz do Mercado o lugar do sagrado. Todo o poder centrado na figura divina de Deus no mundo medieval, é agora transferido para o Mercado, este é agora mais do que 0 palco das trocas, é o palco do valor, o palco do divino. Tem-se portanto a substituição de um D eus pessoal, monoteísta e ético, por outro tão monoteísta e tão ético quanto o primeiro, só que impessoal. Há a soberania do legislador - formas e regras de troca impostas que obrigam a executar contratos reais. Regras poderosas que espelham a magnitude do legislador. Trata-se do comportamento dos indivíduos que refletem - ou refratam - uma postura já presente nos polinésios e nos neozelandezes descritos por Mauss no início do século: "os deuses sabem retribuir o preço das coisas."(1974:63)

O sujeito, depois do resgate da razão pelo Renascimento, sentiu falta do quadro mágico envolvendo aquilo que o fundamenta e mediatiza sua relações com o objeto. A insuportável responsabilidade pela busca de objetos é agora dirigida por um sujeito maior, impessoal; e como não-pessoa impõe-nos necessidades. 0 alvo do desejo do sujeito é, então, o objeto sensível fruto das necessidades. As paixões confundem-se com as necessidades. Os objetos não são mais indivíduos tão incompletos quanto nós, mas coisas que suportam, sem a mínima possibilidade de reação, apesar de sua carga tensa e intensa, o nosso jugo, a nossa ilusão de posse. Exatamente por isso é que cada vez mais sensibilizamos os objeto impregnando-os dessa carga tímicotensiva. Tornam-se portadores de intensidade e extensividade, tornam-se tensos e intensos. A mudança da subjetividade está aí. Somos sujeitos segundos, fundados por um sujeito maior, impessoal, incapazes de mergulhar no delírio das paixões; com isso os objetos de nossos desejos acabam por se tornar objetos impessoais, impotentes perante a paixão, mas sensibilizados, potencializados e por isso capazes de garantir a ilusão de nossa individualidade. 
A teoria das necessidades confere-nos uma posse muito mais definitiva. Um indivíduo jamais suportaria o peso de sentir-se objeto e, até mesmo, o peso de uma subjetividade fundada no eu; por isso a busca é pela posse das coisas, por isso transformar indivíduos em coisas, em produtos de mercado. Objetivá-los, sensibilizá-los, potencializá-los; mas, roubar-lhes a competência para o "tumulto modal" do ser do sujeito, a competência para a paixão - esta só encontra seu pleno espaço nos domínios da loucura, longe da tirania do cotidiano configurado a partir das necessidades. Aliviá-los transformando-os em objetos sensíveis; está aí o papel decisivo da aspectualização no discurso. As escolhas aspectuais, instaladas a partir de um ponto de vista, permitem que a continuidade, proveniente da massa tímico-tensiva, invada o campo discursivo e sobredetermine as descontinuidades narrativas características dos atos de troca fundadores do mercado. Isto assegura uma imprescindível sensibilização ao discurso e, conseqüentemente, aos objetos. Trata-se de garantir construção discursiva dessa subjetividade cravada na impessoalidade, nas necessidades, na objetividade sensível: uma subjetividade pessoal.

A aspectualização toma-se, assim, um mecanismo decisivo para a compreensão da sensibilização do campo discursivo, confirmando a presença da dimensão tímica. Este mecanismo pode ser um caminho para responder à questão proposta por Greimas e Fontanille com relação ao enfoque semiótico mais adequado para abordar o componente passional dos discursos:

A semiótica das paixões deve tomar posição a esse respeito: não se trata de tomar partido entre os desejos e as necessidades, entre as paixões e os interesses - 0 que permanece um debate entre duas culturas - mas de definir um mínimo epistemológico sem o qual não fica assegurada a autonomia da dimensão tímica". (1993:90)

Esse mínimo epistemológico está, justamente, na proposta de mecanismos de geração do sentido, de construção da significação levando em conta transformações sucessivas por meio da composição de campos potencializados pela causa tímico-tensiva, os quais são responsáveis pelas metamorfoses que conferem um outro modo de existência ao sujeito, ao objeto e suas relações específicas. Determinam dessa forma, estratégias discursivas, por meio das quais há um ponto de vista que impregna as projeções no enunciado de uma escolha, de uma dada configuração aspectual envolta na massa tímica originada nas constituições da semântica elementar.

Exatamente neste ponto, percebe-se com precisão o foco principal da questão semiótica do valor: a categoria tímica compreendida a partir dos regimes funcionais operados de acordo com diretrizes sócio-culturais. Faz-se, então, necessário frisar que é preciso compreender uma 
categoria tímica não apenas dimensionada nos limites da individualidade, mas ampliada e enfocada como um "sistema de atrações e repulsões" (Greimas, 1983) fundamentado em determinantes marcados pela cultura, pelo contexto sócio-histórico.

Assim, não seria a oposição desejos vs. interesses examinada em termos de uma subjetividade fundada no indivíduo. Há uma categoria tímica com bases macrossociais, o que torna mais claro o movimento, aparentemente paradoxal, do valor que vai se tornando cada vez mais subjetivo, mas, ao mesmo tempo, vai transformando cada vez mais o desejo em necessidade fundada por um macrosujeito social. Este movimento é, na realidade, um movimento baseado na pessoa e não no indivíduo e dimensionado a partir de um campo impregnado de objetos sensiveis.

É preciso lembrar de Mauss e analisar como a pessoa por ele dimensionada entra em junção com o objeto, adquirindo, assim, o estatuto de sujeito e gerando uma "subjetividade pessoal" em oposição a uma "subjetividade individual"; uma subjetividade pessoal que acaba diluída na objetividade sensível que o mercado impõe.

O valor é uma relação que se estabelece entre sujeito e objeto. Estudar o valor é penetrar nos meandros dessa relação. Observar suas formas, as direções, as intensidades, os limites, as valências e as equivalências entre dois grandes protagonistas do movimento: sujeito e objeto. Fixamos o olhar semiolingüístico sobre a relação que se estabelece entre o sujeito e o objeto e verificamos nos discursos produzidos nas Ciências Sociais - especificamente no discurso das sociedades de mercado e no diálogo que esse discurso produz entre imaginário social e a vida cotidiana - como se processa o modo de existência semiótica desses dois protagonistas - sujeito e objeto - e assim se constitui o valor.

Para a compreensão dessas relações entre sujeito e objeto, estabelecemos aqui alguns pontos que pudessem guiar nossas análises. Observando, sob o ângulo semiolingüístico, a forma por meio da qual as relações entre sujeito e objeto se concretizam, chegamos ao conceito de valor como um sintagma, do qual fazem parte três paradigmas: o lingüístico, o antropológico e 0 tímico-tensivo. Esses três paradigmas obedecem a uma sintaxe de combinação e assim compõem 0 valor.

Tem-se, então, o primeiro paradigma correspondente ao campo de equivalências, a partir do qual são fixadas identidades e diferenças como as primeiras articulações semânticas que irão 
gerar os investimentos mínimos de sentido sobre os quais o valor começa a ser construído. Esses investimentos mínimos de sentido, essas identidades e diferenças, sofrem desde já a intervenção do paradigma tímico-tensivo, pois há a sobredeterminação sensível, por meio da categoria tímica, tornando o que era um campo de equivalências o lugar da constituição das valências: valências de intensidade, responsáveis pelas morfologias que guiam a percepção; e as valências de extensividade, referentes à energia que irá compor essa percepção. Formam-se, a partir das valências neste campo sensibilizado, um proto-sujeito e um proto-objeto. Tudo isso compõe a substância que já sofreu as primeiras formalizações e irá projetar os valores no campo discursivo. Este é o campo semântico elementar, o paradigma das primeiras formalizações, o paradigma lingüísticos sobre o qual atua, desde as primeiras modelizações, o paradigma tímico-tensivo.

Este campo de equivalências sensibilizado projeta, numa sintaxe descontínua de transformações, os investimentos elementares e, assim, o que era um proto-sujeito e um protoobjeto assume a forma dos dois grandes personagens narrativos - sujeito e objeto - que adquirem existência semiótica graças a função juntiva estabelecida entre eles: esta função é precisamente a relação de valor. Temos, portanto, o valor como uma função narrativa de caráter intrinsecamente dinâmico, pois está sobre 0 eixo das conjunções e disjunções que direcionam o percurso narrativo; isto é, o caminho que toma o desejo do sujeito e impulsiona sua busca em direção àquilo que para ele é valor, o objeto de valor. Este percurso de transformações compõe 0 paradigma antropológico do conceito de valor, um paradigma que impõe a presença do sujeito.

Essas descontinuidades narrativas envoltas no campo sensibilizado serão realizadas no campo discursivo, por meio dos mecanismos da enunciação. 0 campo discursivo apresenta estratégias criadas entre enunciador e enunciatário que farão os valores narrativos tomarem forma na veredicção construída pelo discurso. Projeta-se, em função desta veredicção discursiva, um tipo de enunciação que pode privilegiar o sujeito ou o objeto, e assim serão compostos discursos objetivos ou discursos subjetivos, comportando valores objetivos ou valores subjetivos, de acordo com o efeito de sentido que se esteja almejando alcançar. Temos, então, 0 efeito de sentido de objetividade ou o efeito de sentido de subjetividade. D essa forma, podemos constatar que o campo das determinações elementares e o campo discursivo acabam sendo dois campos que envolvem o eixo das descontinuidades narrativas e se intercruzam por meio das projeções sensibilizadas da massa tímico-tensiva. 
É importante notar também que o terceiro paradigma do conceito de valor não coincide exatamente com a proposta clássica do percurso gerativo. 0 paradigma tímico-tensivo é o responsável pela sensibilização do discurso e essa sensibilização vai sendo construída desde 0 nível elementar. 0 paradigma tímico-tensivo deve ser compreendido como um campo de força que polariza os investimentos semânticos elementares, é responsável pela tensão que se estabelece entre sujeito e objeto e é responsável, também, pelo ponto de vista sensível que sobredetermina o discurso. Este paradigma é aquele que dá à significação o caráter tensivo e polarizado.

Paradigma lingüístico, paradigma antropológico e paradigma tímico-tensivo da constituição do conceito de valor atuam até 0 eixo narrativo. 0 campo discursivo irá projetar 0 valor e situá-lo no jogo das estratégias estabelecidas entre enunciador e enunciatário. Ao propormos um modelo para a compreesão do conceito de valor, fomos levados a também propor uma leitura da forma clássica do percurso gerativo, assumindo-o também como o jogo de forças entre dois campos - 0 elementar e o discursivo -, os quais são sustentados por um potente eixo descontínuo: a narrativa.

Finalizando, agradeço a colaboração dos amigos, Prof. Dr. Ramon Américo Vasquez e Prof a Shirley Adriana Souza Silva, que tornaram possível a realização deste artigo.

\section{Referências Bibliográficas}

ASSIS D A SILVA, I. [1995] Figurativização e Metamorfose: 0 mito de Narciso. São Paulo: UNE SP.

BARRO S, D . L. P. de. [1988] Teonia do Discurso - fundamentos semióticos. São Paulo: Atual.

BARTHES, R. [1987] Mitologias. São Paulo: Berthrand Brasil - DIFEL.

BASTIDE, F. [1987] Le traitement de la matiére, in: Actes Sémiotiques - Documents, Group de recherches sémio-linguistiques, Paris, 9 (39).

BERTRAND , D . [1987] La Justesse, in: Semiotic Inquiry. Association canadienne de sémiotique, Montréal, v.13. . [1994] Sémiotique et Èthique - discours des crise, dans la presse hebdomadaire française, in: RO MERA, J. (org.). Semiótica(s). Homenaje a Greimas. Madrid: Instituto de Semiótica Literária y Teatral, Visor Libros, p. 67-84.

. [1995] Anotações do curso A representação dos Valores. D epartamento de Lingüística - FFLCH/ USP.

FIORIN, J. L. e LAND OWSK I, E. (org.) [1997] 0 Gosto da Gente, Gosto das Coisas. São Paulo: EDUC.

FONTANILLE, J. e ZILBERBERG, Cl. [1996a] Valence, Valeur. Nouveaux Actes Sémiotiques, 46-47. Pulim, Université de Limonges.

[1996b] Grammaire Tensive. G rupo de Investigações Sêmio-Lingüísticas da Escola de altos Estudos. Paris. . [2001] Tensão e Significação. São Paulo: Humanitas.

GOFFMAN, E. [1985] As Representações do Eu na Vida Cotidiana. Rio de Janeiro: Zahar.

G REIMAS, A. J. [1970] Du Sens. Paris: Seuil. . [1973] Semântica Estrutural. São Paulo: Cultrix.

--- [1981] Semiótica e Ciências Sociais. São Paulo: Cultrix.

. [1983] Du Sens II: éssais sémiotiques. Paris Seiul. . [1994] Testemunhos. São Paulo: PUC-SP/ USP.

. [2002] Da Imperfeição. São Paulo: Hacker. 
e COURTÉS, J. [1983] Dicionário de Semiótica. São Paulo: Cultrix, 1983.

e COURTÉS, J. [1986] Sémiotique - Dictionnaire Raisonné de la Théorie du Langage. Paris: Hachette. e FONTANILLE, J. [1993] Semiótica das Paixões. São Paulo. Ática.

HJELMSLEV, L. [1975] Prolegômenos a uma Teoria da Linguagem. São Paulo: Perspectiva.

HUNT, E. K. [1989] H istória do Pensamento E conômico. Rio de Janeiro: Campus.

JAKO BSO N, R. [1972] Lingüística e Comunicação. São Paulo: Cultrix.

LAND OWSKI, E. [1991] Dois Ensaios de Sociossemiótica. São Paulo, FFLCH/ USP.

LEVI-STRA USS, Cl. [1971] L'H ome Nu - Mythologiques IV. Paris: Plon.

LOPES, E. [1997] Identidade e Diferença. São Paulo: EDUSP.

MAUSS, M. [1974] Sociologia e Antropologia. São Paulo: Pedagógica Universitária - EDUSP.

SAUSSURE, F. [1975] Curso de Lingüística Geral. São Paulo: Cultrix, 1975.

TRO UBETSKOY, N. [1976] Princípios de Fonologia. Madrid: Cincel.

ZILBERBERG , Cl. [1981] Essai sur les modalités tensives. Amsterdã: Benjamins.

. [1996] Principes de Grammaire Tensive. Grupo de Investigações Sêmio-Lingüísticas da Escola de altos Estudos. Paris. 